\title{
Finansal Oranları Kullanarak Havayolu Şirketlerinin Performans Değerlendirmesi
}

\section{Performance Evaluation of Airlines Using Financial Ratios}

\author{
Așır Özbek ${ }^{1}$ iD, Masoumeh Ghouchi ${ }^{2}$ \\ ${ }^{1}$ Kirlkkale Üniversitesi, Kirlkkale MYO, Bil. Tek. Böl. 71450 Kirlkkale, TÜRKIYE \\ ${ }^{2}$ Kırıkkale Üniversitesi, Sosyal Bilimler Enstitüsü, İşletm. Böl. 71450 Kırıkkale, TÜRKIYE
}

Başvuru/Received: $31 / 12 / 2020$

Kabul / Accepted: 11/03/2021

Çevrimiçi Basım / Published Online: 23/05/2021

Son Versiyon/Final Version: 18/06/2021

\section{$\ddot{O} \mathbf{z}$}

Küreselleşen ve hızla gelişen dünya ekonomisinde, ülkelerin sosyokültürel ve ekonomik gelişiminde büyük pay sahibi olan ve rekabetin artmasına katkı sağlayan en önemli faktörlerden biri de hızla büyüyen ve gelişen havayolu taşımacılığıdır. Bu çalışmanın amacı da Çok Kriterli Karar Verme (ÇKKV) yöntemlerinden olan Weighted Aggregated Sum Product Assessment (WASPAS) ve Evaluation Based on Distance from Average Solution (EDAS) yöntemleri kullanılarak Avrupa'nın önde gelen 5 havayolu şirketinin 2009-2018 yıllarındaki on yıllık finansal performansını değerlendirmektir. Bu amaç doğrultusunda değerlendirmeye alınan 5 havayolu şirketinin bilançolarından elde edilen finansal oranlar, ÇKKV yöntemlerinden olan WASPAS ve EDAS yöntemleri ile analiz edilmiştir. Çalışmada kullanılan "cari oran", "asit test oranı", "nakit oranı", "finansal kaldıraç oranı", "aktif devir hızı", "alacak devir hızı", "duran varlıklar devir hızı", "özsermaye karlılı̆̆ı", "aktif karlılığı", "faaliyet kâr marjı", "brüt kâr marjı" ve "net kâr marjı" olmak üzere toplamda 12 adet değerlendirme kriteri literatür çalışması neticesinde belirlenmiştir. Kriter ağırlıkları Entropi yöntemiyle belirlenmiştir. Havayolu şirketleri bu kriterlere göre belirtilen yöntemler ile 2009-2018 yıllarındaki performansı değerlendirilmiş ve şirketlerin performanslarına göre sıralamaları yapılmıştır. Avrupa'nın önde gelen 5 havayolu şirketinin finansal oranlara göre analiz edilmesi neticesinde performansı en yüksek firmanın Ryanair olduğu ortaya konmuştur. Son sırada ise Lufthansa yer almıştır.

\section{Anahtar Kelimeler}

"Havayolu şirketleri, Finansal Performans, Çok Kriterli Karar Verme, Entropi, WASPAS, EDAS"

\begin{abstract}
A major factor with a large share in the socio-cultural and economic development of countries, contributing to the increase of competition in the globalizing and rapidly developing world economy is the rapidly growing and developing air transport. This study aimed to evaluate the ten-year financial performance of Europe's leading 5 airline companies between 2009 and 2018. Two Multi-Criteria Decision-Making methods (MCDM), the Weighted Aggregated Sum Product Assessment (WASPAS) and the Evaluation based on Distance from Average Solution (EDAS), were employed in the study. The financial ratios obtained from the balance sheets of 5 airline companies were analyzed using WASPAS and EDAS methods. The 12 criteria determined for the assessment in light of the literature study were "current ratio", "acid test ratio", "cash ratio", "financial leverage ratio", "asset turnover rate", "receivable turnover rate", "fixed assets turnover rate", "return on equity", "asset "Profitability", "operating profit margin", "gross profit margin" and "net profit margin". Criterion weights were determined by the Entropy method. The 2009-2018 performances of the 5 airline companies were evaluated and the companies were ranked according to the results. The study revealed that Ryanair showed the best performance, while Lufthansa was found to be the one with the lowest efficiency.
\end{abstract}

\section{Key Words}

"Airline companies, Financial Performance, Multi Criteria Decision Making, Entropi, WASPAS, EDAS" 


\section{Giriş}

Günümüzde hızlı bir şekilde büyüyen ve gelişen ulaşım ve taşımacılık sektörü, ülkelerin sosyokültürel ve ekonomik kalkınmalarına katkı sağlayan en önemli faktörlerden birisidir. Taşımacılık hizmeti, canlı veya cansız olan her varlığın zamandan tasarruf sağlayarak bir mekândan farklı bir mekâna kolaylıkla gitmesini sağlayan bir hizmettir. Taşımacılık; sağladığı zaman faydasının yanı sıra ekonomik ve elverişli mekân değişimine de imkân sağladığı ölçüde değerli olur ve böylece dünyanın her bölgesinde mekân ve zaman ilişkileri kurulmuş olur. Taşımacılıkta uygun firsatların varlığı veya yokluğu birçok ulusun, bölgenin, şehrin, sanayinin, kurumların, işletmelerin gelişmesine veya geri kalmasına neden olmuştur (Gerede, 2015:3). Yüzyıllardır sürekli gelişmekte olan ulaşım ve taşımacılık, insanların yaşamlarındaki ekonomik ve sosyokültürel gelişimleri için yaşamsal bir faktördür. Dünyada 20. Yüzyılın başlarında ticari uçuşların da başlamasıyla birlikte havacılık endüstrisinin gelişmesi daha da ivme kazanmıştır. 1970'lerde ABD'nin iç hatlarda başlattı̆̆ serbestleşmenin etkisiyle yayılan liberalleşme birçok ülkeyi de etkileyerek, dünyada sivil havacılık için yeni bir dönem başlatmıştır (Aldemir ve Kuyucak Şengür, 2018: 142). Küreselleşen ve hızla gelişen dünya ekonomisi, artan rekabet ve uluslararası lojistik alanındaki gelişmeler ile ulaşım sektöründe havayolu taşımacıllğı da son yıllarda oldukça önem kazanmıştır.

İşletmelerin en önemli kontrol işlevlerinden birisi de finansal performans ölçümüdür. Finansal veriler, yönetim performansı raporlarını oluşturan, yönetsel başarı veya başarısızlığı doğrulayan ve gelmekte olan zorlukların sinyallerini oluşturan ve habercisi olan ticari işletmelerin göstergeleridir. Kaynakların kısıtlı olduğu rekabetçi bir ortamda, finansal performans ölçümü ve yönetimi çok önemlidir. Finansal performans kriterleri işletmelerin rekabet gücünü yansıttı̆̆ından dolayı finansal performansın doğru ve uygun bir şekilde değerlendirilmesi oldukça önemlidir (Feng ve Wang, 2000: 134; Safaei Ghadikolaei vd., 2014: 275). Finansal performans, şirketlerin mali değerleri ile hesaplanan kar ve zarar arasındaki doğru ve uygun ilişkinin kurulması ve şirketin finansal gücünün ve zayıflıklarının belirleme sürecini oluşturmaktadır. İşletmelerdeki bu süreç karar alıcılar ve yöneticiler açısından oldukça önemlidir (Al Masum ve TuzJohora, 2012: 38). Dünyada havayolu şirketlerinin yoğun rekabeti nedeniyle, finansal performanslarını ölçmek ve analiz etmek daha da önemli hale gelmiştir. Finansal performans, işletmelerin yaptıkları yatırım faaliyetlerinin güvenilirliğini ve riskini değerlendirmede ve genel anlamda işletmenin geleceğine dair alacağı finansal kararlarda oldukça önemlidir.

Günümüzde seçeneklerin çok olmasının yanı sıra, karar sürecinde etkili olan kriterler de çeşitlenerek çoğalmıştır. İşletmeler, yatırımcılar ve analistler de küreselleşen piyasalarda ortaya çıkan finansal krizlerin, farklılıkların ve yeni risklerin oluşturduğu belirsizlik, sorunlarının çözümü, varlıklarının devamı için karar verme sürecinin etkin olarak kullanmaktadırlar. Günümüzde işletmelerin karşı karşıya kaldıkları sorunların ve risklerin çözümünde finansal tabloların değerlendirilmesinin yanı sıra çok kriterli karar verme (ÇKKV) yöntemlerini de kullanarak etkin bir finansal yönetimin olması sağlanmıştır.

Bu çalışmada ÇKKV yöntemlerinden WASPAS (Weighted Aggregated Sum Product Assessment) ve EDAS (Evaluation Based on Distance from Average Solution) yöntemleri kullanılarak Avrupa'nın önde gelen beş havayolu şirketinin 2009-2018 yıllarındaki on yıllık finansal performansı değerlendirilmiştir. Finansal veriler firmaların hem belirli bir zamanın hem de geçmiş yıllara ait durumlarını gösterir. Değerlendirilmeye alınan Air France (KLM), Easyjet, Lufthansa, Ryanair ve Türk Hava Yolları (THY) şirketlerin finansal performans analizi ve ölçülmesi için bilançolarından elde edilen finansal oranlar ÇKKV yöntemlerinden olan WASPAS ve EDAS ile analiz edilmiştir. Literatür çalışması neticesinde 4 başlıkta toplam 12 finansal oran, kriter olarak belirlenerek havayolu şirketlerinin 2009-2018 yıllarındaki on yıllık finansal performansı değerlendirilerek başarı sıralaması elde edilmiştir Kriter ağırlıkları nesnel uygulamalara uygun olan Entropi yöntemi ile belirlenmiştir.

Çalışmanın ikinci bölümüne havayolu şirketlerinin performansını ölçmeye yönelik yapılan çalışmalara değinilmiştir. Üçüncü bölümde çalışmada kullanılan yöntemler detaylı olarak tanıtılmıştır. Dördüncü bölümde akış şeması formatında çalışmanın sürecini gösteren bir model geliştirilmiş ve çalışmanın bulgularına yer verilmiştir. Son bölümde ise çalışma değerlendirilmiş ve gelecekte bu konularda çalışmak isteyen araştırmacılara önerilerde bulunulmuştur.

\section{Literatür Araştırması}

Akkaya (2004), finansal oranlar yardımıyla havayolu firmalarının performanslarını gri bölge ve TOPSIS (Technique for Order Preference by Similarity) yöntemini kullanarak değerlendirmiştir. Wang (2008), yaptığı çalışmada Tayvan havayollarının finansal performansını Bulanık ÇKKV yöntemi ile analiz etmiştir. Çalışmada finansal oranları kümelemek ve temsili göstergeler bulmak için gri ilişki analiz yöntemi kullanılmıştır. Wang ve Kao (2009), Bulanık ÇKKV yöntemini kullanarak Tayvan'daki üç yerel havayolunun finansal performanslarını değerlendirmişlerdir. Ömürbek ve Kınay (2013), Borsa İstanbul'da (BIST) faaliyet gösteren bir havayolu şirketi ile Frankfurt Menkul Kıymetler Borsası'nda faaliyet gösteren bir havayolu şirketinin performans göstergelerini kullanarak TOPSIS yöntemi ile finansal performanslarını değerlendirmişlerdir. Barros ve Wanke (2015), Afrika merkezli 29 havayolu işletmesinin 2010-2013 yıllarındaki nisbi verimliliğini TOPSIS, Sinir Ağları ve DEAP yöntemleri ile ölçmüşlerdir. Ölçümde; "çalışan sayısı”, "toplam uçak sayısı", "işletme maliyetleri”, "ücretli yolcu kilometresi başına gelir" ve "ücretli tonaj kilometresi başına gelir" kriterleri kullanılmıştır. Wanke vd. (2015), "işletme maliyeti”, "amortismanlar", "maaş", "çalışanlar", "uçaklar”, "toplam aktifler", "duran varlıklar", "gelirler", "fvök", "yolcu sayısı" ve "yolcu mili başına gelir" kriterlerine göre Asya merkezli 35 havayolu işletmesinin 20062012 yıllarındaki performansının TOPSIS ve Markov Zinciri Monte Carlo Metodu yöntemleriyle ölçmüşlerdir. Teker vd. (2016), 20112014 dönemi için en iyi 20 havayolunun finansal performansını analiz etmişlerdir. Çalışmada havayollarının finansal performansı kısa 
ve uzun vadeli şirket kararlarını etkilemekte ve stratejik planlamayı şekillendirmekte olduğu görülmüştür. Akgün ve Soy Temür (2016), mali yapı, faaliyet ve karlılık oranlarını kullanarak Pegasus ve THY işletmelerinin 2010-2015 yıllarındaki finansal performansını TOPSIS yöntemiyle ölçmüşlerdir. Sakız (2017), yaptığı çalışmada havayolu sektöründe finansal oranlar kullanılarak, finansal risk değerlendirme modellerinden biri olan Altman Z'nin notunu incelemiş ve THY'nin son 3 yılda üç aylık mali verilerini içeren bir uygulama gerçekleştirmiştir. Asker (2017), petrol fiyatlarının en yüksek seviyeye ulaştığı 2012 yılından sonrasını baz alarak dünyanın farklı bölgelerinde faaliyet gösteren 16 havayolu işletmesinin etkinliğini Veri Zarflama Analizi (VZA) yöntemini kullanarak incelemiştir. Gümüş ve Bolel (2017), BİST'de faaliyet gösteren THY firması ile Pegasus firmasının 2010-2015 dönemine ait finansal performanslarını rasyo tekniği eşitlikleriyle analiz etmişlerdir. Avcı ve Çınaroğlu (2018), Analitik Hiyerarşi Süreci (AHS) ve TOPSIS yöntemlerini kullanarak Avrupa'nın beş havayolu işletmesinin 2012-2016 dönemine ait finansal performanslarını değerlendirerek sıralamalarını yapmışlardır. Perçin ve Aldalou (2018), çalışmalarında bütünleşik bulanık AHS ve bulanık TOPSIS yöntemleriyle bir finansal analiz modeli oluşturmuşlardır. Oluşturulan bütünleşik bulanık AHS ve bulanık TOPSIS modelini kullanılarak BİST'de işlem gören havacılık sektöründe çalışan şirketlerin finansal performansları değerlendirilmiştir. Battal (2018), The Decision Making Trial and Evaluation Laboratory (DEMATEL) yöntemini kullanarak Türkiye'deki havayolu işletmelerinin finansman sorunları inceleyerek sorunlar arasındaki neden sonuç ilişkisi, ilişki düzeyi ve öncelik durumunu açıklamaya çalışmıştır. Dalak vd. (2018), Türkiye'de halka açık olan ve olmayan havayolu yolcu taşımacılığı şirketlerinin finansal analiz tekniklerinden faydalanma durumlarını karşılaştırmalı olarak incelemişlerdir. Kaya ve Kendirli (2018), Türkiye'deki havayolu işletmelerinin uygulamaları açısından Hedging yönteminin kullanılmasını incelemiş ve Hedging uygulamalarına bakılarak, havayolu işletmelerinin mali tablolarındaki etkilerini değerlendirilmeye çalışmışlardır. Kiracı ve Asker (2019), havayolu şirketlerinin etkinliklerinin yıllara göre değişimini inceleyerek bu etkinlikleri belirleyen faktörleri ortaya çıkarmışlardır. Çalışmada 2010-2016 dönemine ait dünyanın farklı bölgelerinde faaliyet gösteren 45 havayolu işletmesini VZA ve Tobit Regresyon (TR) yöntemini kullanarak incelemişlerdir. Kiracı ve Bakır (2019), havayolu firmalarının küresel finans krizi öncesi ve sonrası performansının ÇKKV yöntemlerini kullanarak incelemişlerdir. Bu doğrultuda 20052012 dönemine ait 13 havayolu işletmesinin performansını EDAS yöntemini kullanarak değerlendirmişlerdir. Kriterlerin ağırlıklarını ise CRITIC yöntemiyle belirlemişlerdir. Çetin ve Altan (2019), bulanık TOPSIS yöntemini kullanarak Ankara Esenboğa Havalimanı'nda hizmet veren 3 havayolu şirketinin performansını değerlendirmişlerdir.

Havayolu şirketlerinin mali performansını ölçmeye yönelik birçok çalışma literatürde yer almasına rağmen, çalışmanın konusunu teşkil eden havayolu şirketlerinin performansını ölçmeye yönelik Entropi, WASPAS ve EDAS yöntemlerinin bütünleşik olarak kullanıldığı bir çalışmaya rastlanmamıştır. Bu açıdan yapılan bu çalışmanın alana katkı sağlayacağı düşünülmekte ve farklı yöntemlerin de kullanılabilirliğinin görülmesi açısından literatürde boşluğu dolduracağı umulmaktadır.

\section{Yöntemler}

\subsection{Entropi Yöntemi}

Entropi kavramı literatürde ilk kez Rudolph Clausius (1865) tarafından bir sistemdeki düzensizliğin ve belirsizliğin bir ölçüsü olarak tanımlanmış ve Shannon (1948) tarafından enformasyon teorisine uyarlanmıştır (Zhang vd., 2011: 444). Entropi yöntemi mevcut verinin sağladığı faydalı bilginin miktarını ölçmede kullanılmaktadır (Wu, 2011: 5163). Yöntemin en önemli özelliği, çeşitli ölçeklerde uygulama olanağı bulması ve nesnel değerlendirme yapabilmesidir.

Entropi Yöntemi 5 adımdan oluşmaktadır (Karami ve Johansson, 2014: 523-524 ve Wang ve Lee, 2009: 8982):

Adım 1: Karar matrisinin oluşturulması. Eşitlik (1)'de formüle edildiği gibi ilk olarak seçeneklerin kriterlere göre aldığı değerleri içeren matris oluşturulur.

$$
X=\left[\begin{array}{cccc}
x_{11} & x_{12} & \cdots & x_{1 n} \\
x_{21} & x_{22} & \cdots & x_{2 n} \\
\cdots & \cdots & \cdots & \cdots \\
x_{i 1} & x_{i 2} & \cdots & x_{i n} \\
\cdots & \cdots & \cdots & \cdots \\
x_{m 1} & x_{m 2} & \cdots & x_{m n}
\end{array}\right]
$$

Adım 2: Karar matrisinin normalize edilmesi. Normalizasyon sürecin iki aşamada gerçekleştirilmektedir. İlk aşamada kriterlerin fayda veya maliyet yönüne göre işlem yapılmaktadır. Fayda yönlü kriterler için (2), maliyet yönlü kriterler içinse (3) numaralı Eşitlik kullanılmaktadır.

$$
\begin{aligned}
& r_{i j}=\frac{x_{i j}}{\max _{j} i j} \\
& r_{i j}=\frac{\min _{j} i j}{x_{i j}}, \quad x_{i j} \neq 0
\end{aligned}
$$


$i=1,2, \ldots, m ; j=1,2, \ldots, n$

Normalizasyon işleminin 2. aşamasında ise (4) numaralı Eşitlik kullanılmaktadır.

$f_{i j}=\frac{r_{i j}}{\sum_{i=1}^{n} r_{i j}}$

Adım 3: Entropi hesaplanır. Entropi değerleri Eşitlik (5) kullanılarak hesaplanır.

$e_{j}=\frac{\sum_{i}^{m} f_{i j} \ln f_{i j}}{\ln m}$

Adım4: Entropi ă̆ırlığının hesaplanması. Son aşama olan bu adımda Eşitlik (6) kullanılarak kriterlerin ağırlıkları hesaplanır.

$w_{j}=\frac{1-e_{j}}{n-\sum_{j=1}^{n} e_{j}}$

\subsection{WASPAS Yöntemi}

WASPAS yöntemi ÇKKV yöntemlerinden olan ve oldukça yaygın olarak kullanılan Ağırlıklandırılmış Toplam Model (Weighted Sum Model-WSM) ve Ağırlıklandırılmış Çarpım Model (Weighted Product Model-WPM) yöntemlerini temel alan yeni bir ÇKKV yöntemidir. Çok kriterli problemlerin çözümü için alternatiflerin kriterlere göre performansını değerlendiren WASPAS yöntemi, Zavadskas vd. tarafından 2012 yılında geliştirilmiştir. WASPAS yöntemi çözümü sonucunda seçenekler en iyiden en kötüye doğru sıralanmaktadır. WASPAS yöntemi, 6 aşamadan oluşan bir çözüm sürecini içerir (Özbek, 2019: 43).

Adım 1: Karar matrisinin oluşturulmast. WASPAS yönteminde ilk olarak seçeneklerin belirlenen kriterlere göre değerlerinin gösterildiği başlangıç karar matrisi oluşturulur. Bu matris Eşitlik (7) ile formüle edilmiştir. Bu matriste; m, seçeneklerin; $n$ ise kriterlerin sayısını göstermektedir. $x_{i j}$, i. seçeneğin j. kritere göre performans değerini göstermektedir.

$X=\left[\begin{array}{cccc}x_{11} & x_{12} & \cdots & x_{1 n} \\ x_{21} & x_{22} & \cdots & x_{2 n} \\ \cdots & \cdots & \cdots & \cdots \\ x_{i 1} & x_{i 2} & \cdots & x_{i n} \\ \cdots & \cdots & \cdots & \cdots \\ x_{m 1} & x_{m 2} & \cdots & x_{m n}\end{array}\right]$

Adım 2: Karar matrisinin normalize edilmesi. Karar matrisini normalize etmek için kriterler maliyet yönlü olduğunda (8), fayda yönlü olduğunda ise (9) numaralı Eşitlik kullanılır.

$x_{i j}^{*}=\frac{\min _{i} x_{i j}}{x i j}$

$x_{i j}^{*}=\frac{x_{i j}}{\max _{i} x_{i j}}$

Adım 3: WSM yöntemine göre seçeneklerin göreli performansının hesaplanması. Eşitlik (10) ile formüle edildiği gibi her bir seçeneğin kriter değerlerinin, kriter ağırlıkları ile çarpımının toplanmasıyla WSM yöntemine göre seçeneklerin performansı hesaplanır. $w_{j}$, kriter ağırlıklarını göstermektedir.

$P_{i}^{(1)}=\sum_{j=1}^{n} x_{i j}^{*} w_{j}$

Adım 4: WPM yöntemine göre seçeneklerin göreli performansının hesaplanması. Eşitlik (11) ile formüle edildiği gibi her bir seçeneğin kriter değerlerinin kriter ağırlıklarına göre üssünün alınması ve çarpılmasıyla WPM yöntemine göre seçeneklerin performansı hesaplanir. 
$P_{i}^{(2)}=\prod_{j=1}^{n}\left(x_{i j}^{*}\right)^{w_{j}}$

Adım 5: Seçeneklerin nihai performansının hesaplanması. (12) numaralı Eşitlik kullanılarak seçeneklerin nihai performans değerleri bulunur.

$P_{i}=0.5 P_{i}^{(1)}+0.5 P_{i}^{(2)}$

Karar verme sürecinin sıralama etkinliğini ve doğruluğunu arttırabilmek için Eşitlik (13) kullanılabilir.

$P_{i}=\alpha P_{i}^{(1)}+(1-\alpha) P_{i}^{(2)}$

$\alpha, 0$ ile 1 arasında değer alabilen bir parametredir. WASPAS yöntemi, $\alpha=0$ olarak belirlendiğinde WPM yöntemine ve $\alpha=1$ olarak belirlendiğinde ise WSM yöntemine dönüşmektedir. Karar verici $\alpha$ değerini serbest olarak belirleyebilmektedir. Zavadskas vd. $\alpha$ değeri için 0,5 değerini belirlemiş olmasına rağmen $\alpha$ için en uygun değerin hesaplanmasını önermektedir (Özbek, 2019: 45-46).

Adım 6: Seçeneklerin nihai sıralamalarını belirlenmesi. Seçenekler, $P_{i}$ değerlerine göre en iyiden en kötüye doğru sıralanır. İlk sıradaki seçenek, performansı en yüksek alternatif olarak kabul edilir.

\subsection{EDAS Yöntemi}

EDAS yöntemi ilk olarak Ghorabaee vd. (2015) tarafından geliştirilmiş ve envanter kalemlerinin ABC analizine göre sınıflandırmasını yapmak amacıyla kullanılmış ve geçerliliği test edilmiştir (Kiracı ve Bakır, 2019:159).

EDAS yöntemi aşağıdaki aşamalardan oluşmaktadır (Özbek, 2019:269).

Adım 1: Başlangıç matrisinin (X) oluşturulması. Seçeneklerin kriterlere göre aldığı değerlerin gösterildiği başlangıç karar matrisi Eşitlik (14) ile formüle edildiği gibi oluşturulur. $x_{i j}$, i. seçeneğin j. kritere göre performans değerini göstermektedir. m, seçenek; $\mathrm{n}$ ise kriter sayısını göstermektedir.

$X=\left[X_{i j}\right]_{m x n}=\left[\begin{array}{cccc}x_{11} & x_{12} & \cdots & x_{1 n} \\ x_{21} & x_{22} & \cdots & x_{2 n} \\ \cdots & \cdots & \cdots & \cdots \\ x_{i 1} & x_{i 2} & \cdots & x_{i n} \\ \cdots & \cdots & \cdots & \cdots \\ x_{m 1} & x_{m 2} & \cdots & x_{m n}\end{array}\right]$

Adım 2: Tüm kriterlere göre ortalama çözümün belirlenmesi. Her bir kritere göre seçeneklerin ortalama değeri Eşitlik (15) yardımıyla elde edilir.

$A V_{j}=\frac{\sum_{i}^{m} X_{i j}}{m}$

$A V=\left[A V_{j}\right]_{1 x n}$

Adım 3: Ortalamadan pozitif uzaklık ve negatif uzaklık matrisi oluşturulur. Kriterler fayda yönlü oldukları zaman PDA (ortalamadan pozitif uzaklık) ve NDA (ortalamadan negatif uzaklık) matrisleri (19) ve (20) numaralı Eşitlikler ile, maliyet yönlü oldukları zamanda ise (21) ve (22) numaralı Eşitlikler ile oluşturulur (Özbek ve Engür, 2018: 422).

$P D A=\left[P D A_{i j}\right]_{m x n}$

$N D A=\left[N D A_{i j}\right]_{m x n}$

$P D A_{i j}=\frac{\max \left(0,\left(X_{i j}-A V_{j}\right)\right)}{A V_{j}}$

$N D A_{i j}=\frac{\max \left(0,\left(A V_{j}-X_{i j}\right)\right)}{A V_{j}}$ 


$$
\begin{aligned}
P D A_{i j} & =\frac{\max \left(0,\left(A V_{j}-X_{i j}\right)\right)}{A V_{j}} \\
N D A_{i j} & =\frac{\max \left(0,\left(X_{i j}-A V_{j}\right)\right)}{A V_{j}}
\end{aligned}
$$

Adım 4: PDA ve NDA matrislerinin ağırlıklandırılması. Bu aşamada indisi aynı kriterlerin ağırlık değeri ile PDA ve NDA matrislerinin elemanları çarpılarak PDA ve NDA matrisleri ağırlıklandırılır (Özbek, 2019:274).

Adım 5: Seçeneklerin ağırlıklandırılmış PDA ve NDA değerlerinin toplanması. Her bir seçeneğin kriterlere göre ağırlıklandırılmış değerleri toplanır. Toplam pozitif uzaklık (SP) değerleri Eşitlik (23), toplam negatif uzaklık (SN) değerleri ise Eşitlik (24) kullanılarak hesaplanır.

$$
\begin{aligned}
& S P_{i}=\sum_{j=1}^{n} v_{j} P D A_{i j} \\
& S N_{i}=\sum_{j=1}^{n} v_{j} N D A_{i j}
\end{aligned}
$$

Adım 6: Seçeneklerin SP ve SN değerlerinin normalize edilmesi. Her bir seçeneğin toplam pozitif uzaklık (SP) ve toplam negatif uzaklık (SN) normalize değerleri, Eşitlik (25) ve (26) kullanılarak hesaplanır.

$$
\begin{aligned}
& N S P_{i}=\frac{S P_{i}}{\max _{i}\left(S P_{i}\right)} \\
& N S N_{i}=1-\frac{S N_{i}}{\max _{i}\left(S N_{i}\right)}
\end{aligned}
$$

Adım 7: Sıralama puanının hesaplanması. Her bir seçeneğin normalize toplam pozitif (NSP) ve normalize toplam negatif (NSN) puanlarının ortalaması alınarak seçeneklerin nihai performansı (AS) elde edilir.

$A S_{i}=\frac{1}{2}\left(N S P_{i}+N S N_{i}\right)$

$A S_{i}$ değeri, $0 \leq A S_{i} \leq 1$ koşulunu sağlamalıdır.

Adım 8: Seçenekler, AS puanına göre azalan düzeyde sıralanır. Nihai performans puanları büyükten küçüğe doğru sıralanır. İlk sıradaki seçenek en yüksek performansa sahip seçenek olarak kabul edilir.

\section{Model, Veri Seti ve Bulgular}

Avrupa'nın önde gelen 5 havayolu şirketinin 2009-2018 yılları arasındaki finansal performansını değerlendirmek için ÇKKV yöntemlerinden Entropi, WASPAS ve EDAS yöntemleri kullanılmıştır. Değerlendirme süreci için geliştirilen model akış şeması formatı şeklinde Şekil 1'de verilmiştir.

\subsection{Model}

Şekil 1'de gösterilen model, dört ana kısımdan oluşturulmuştur. Modelde görüldüğü gibi birinci kısmı oluşturan hazırlık aşaması; problemin tanımlanması, seçeneklerin ve kriterlerin belirlenmesi ve kriterlerin Entropi yöntemi ile ağırlıklandırılması sürecinden oluşmaktadır. Bir sonraki adım olan karar matrislerinin oluşturulması aşamasında ise her yıl için 1 adet karar matrisi oluşturulmaktadır. Toplamda 10 adet karar matrisi oluşturulur. Bu matrisler ekte Tablo 8-18'de verilmiştir. Döngü süreci bu işlemi göstermektedir. Bu oluşturulan matrisiler her iki yöntemin temel aldığı verileri içermektedir. 3. aşamada WASPAS yöntemi ile seçenekler analiz edilmektedir. Bu işlem her yıl için yapıldığından 10 havayolu şirketinin her yıla ait performans sıralaması gerçekleşmektedir. 4. aşama olan son safhada ise EDAS yöntemi ile seçenekler analiz edilmektedir. Bu sürecin sonucunda da her yıl için performans sıralaması elde edilmektedir. Her iki yönteme göre elde edilen bulgular karşılaştırılıp yorumlanmaktadır. Son olarak da havayolu şirketler yıllara göre ve bütüncül olarak değerlendirilerek sonuçlar yorumlanmaktadır. 


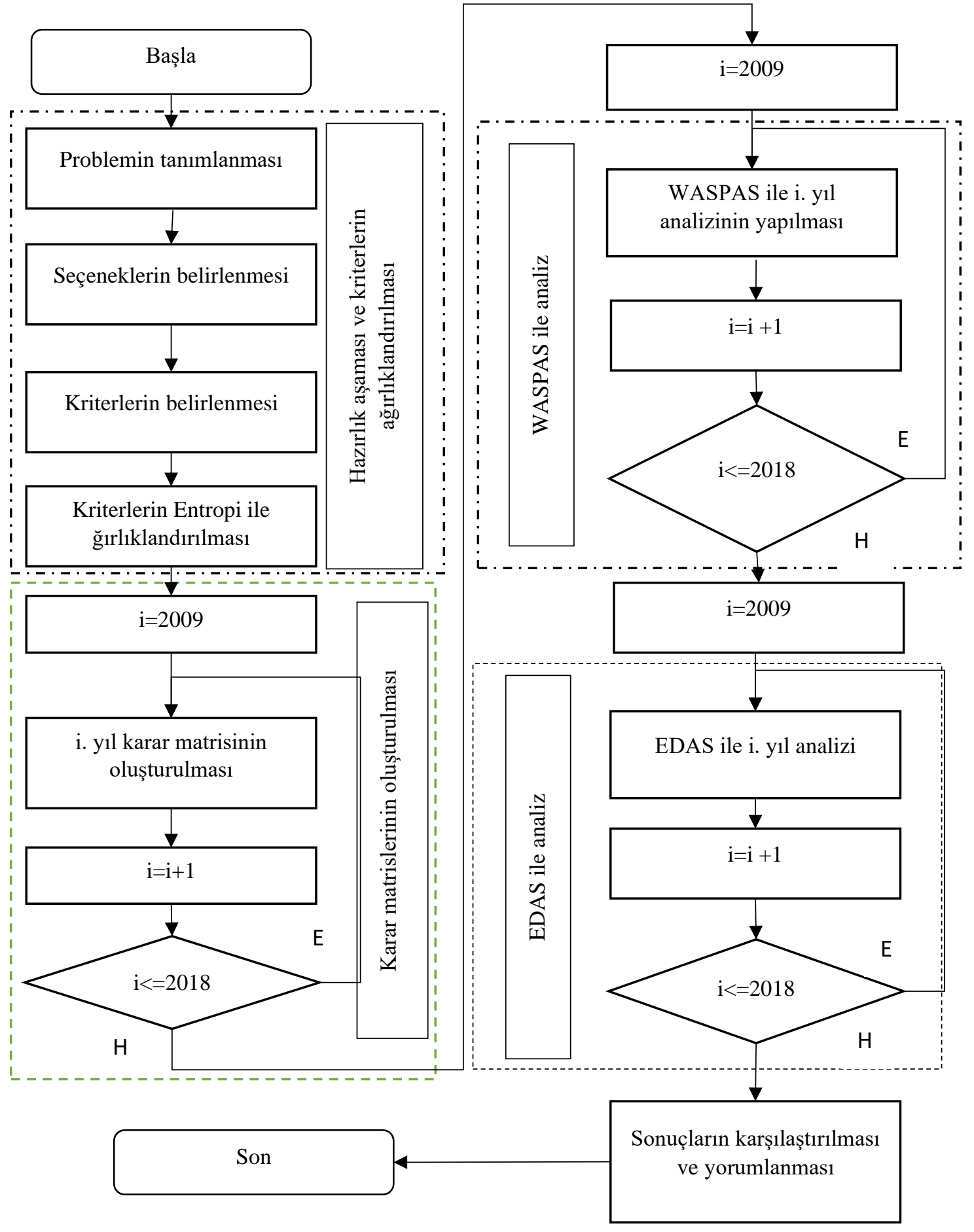

Şekil 1. Havayolları Şirketlerinin Performansını Değerlendirme Modeli

\subsection{Değerlendirme Kriterleri}

Araştırmanın amacı, Avrupa'nın önde gelen 5 havayolu şirketinin 2009-2018 yılları arasındaki on yıllık finansal performanslarını Entropi, WASPAS ve EDAS yöntemleri ile değerlendirilmesi ve çıkan sonuçların birbirleriyle karşılaştırılması ve karşılaştırma neticesinde anlamlı bilgilere ulaşılmasıdır. Veriler, belirtilen firmaların 2009-2018 yılları arası bilanço ve gelir tablolarından elde edilmiştir. Çalışmanın konusunu oluşturan havayolu şirketleri alfabetik sırada Tablo 1'de verilmiştir.

Değerlendirmede kullanılan kriterler "likidite oranları", "mali oranlar", "faaliyet oranları" ve "karlılık oranları" başlığı altında gruplandırılmıştır. "Cari oran", "asit test oranı", "nakit oranı", "finansal kaldıraç oranı", "aktif devir hızı", "alacak devir hızı", "duran varlıklar devir hızı", "özsermaye karlılığı", "aktif karlılığı", "faaliyet kâr marjı”, "brüt kâr marjı”, "net kâr marjı” olmak üzere toplamda 12 kriter literatür çalışması neticesinde belirlenmiştir. "Finansal kaldıraç oranı" kriteri maliyet yönlü iken diğer kriterler fayda yönlüdür. 
Finansal performans analizinde kullanılan finansal oranlar ve eşitlikler Tablo 2'de verilmiştir. Çalışmada analizler iki farklı yaklaşımla gerçekleştirilmiştir. İlk olarak kriter ağılıkları eşit olarak belirlenmiş ve 2. yaklaşımda ise kriter ağırlıkları Entropi yöntemine göre nesnel olarak hesaplanmış ve analizlerde bu kriter ağırlıkları kullanılmıştır.

Tablo 1. Değerlendirmeye Dâhil Edilen Havayolu Firmaları

\begin{tabular}{ll}
\hline SNo & Firma Adı \\
\hline 1 & Air France (KLM) \\
2 & Easyjet \\
3 & Lufthansa \\
4 & Ryanair \\
5 & THY
\end{tabular}

Tablo 2. Finansal Performans Değerlendirme Kriterleri

\begin{tabular}{|c|c|c|}
\hline Ana Kriterler & Alt Kriterler & Tanım \\
\hline \multirow{3}{*}{ Likidite Oranları } & Cari Oran & $\begin{array}{l}\text { Dönen Varlıklar/ Kısa Vadeli Yabancı } \\
\text { Kaynaklar }\end{array}$ \\
\hline & Asit Test Oranı & $\begin{array}{l}\text { Dönen Varlıklar- Stoklar/ Kısa Vadeli } \\
\text { Yabancı Kaynaklar }\end{array}$ \\
\hline & Nakit Oran & $\begin{array}{l}\text { Hazır Değerler/ Kısa Vadeli Yabancı } \\
\text { Kaynaklar }\end{array}$ \\
\hline \multirow[t]{2}{*}{ Mali Oranları } & Finansal Kaldıraç Oranı & Toplam Borçlar/ Toplam Aktifler \\
\hline & Aktif Devir Hızı & Net Satışlar/ Toplam Aktifler \\
\hline \multirow[t]{4}{*}{ Faaliyet Oranları } & Alacak Devir Hızı & Net Satışlar/ Ticari Alacaklar \\
\hline & Duran Varlıklar Devir Hızı & Net Satışlar/ Duran Varlıklar \\
\hline & Özsermaye Karlılığı & Net Kar/ Özkaynaklar \\
\hline & Aktif Karlılığ & Net Kar/ Toplam Aktifler \\
\hline \multirow[t]{3}{*}{ Karlılık Oranları } & Faaliyet Kar Marjı & Faaliyet Karı/ Net Satışlar \\
\hline & Brüt Kar Marj1 & Brüt Satış Karı/ Net Satışlar \\
\hline & Net Kar Marjı & Net Kar/ Net Satışlar \\
\hline
\end{tabular}

Likidite oranlarl: Firmaların kısa vadeli borçlarının ödeme gücünün ölçülmesi ve çalışma sermayelerinin yeterli olup olmadığının belirlenmesi için kullanılan oranlardır.

Cari oran: Şirketlerin kısa vadeli yabancı kaynaklarını karşılayabilme gücünü ölçmek ve çalışma sermayelerinin yeterli olup olmadığının belirlenmesi için kullanılan bir orandır. Cari oran değeri 1'den küçük olduğunda, firmalar için kısa vadeli borçlarını ödemek zor olmaktadır.

Asit test oranı: Bir işletmenin bilanço değerlerinin kısa vadeli yükümlülüklerin karşılanması için kısa vadeli varlıklara sahip olup olmadıklarını gösteren bir orandır.

Nakit oranı: İşletme satışlarının durması ve alacaklarının tahsil edilmemesi durumu; kısa vadeli borçları karşılama gücünü göstermektedir.

Mali yapı oranları: Şirketlerin mali yapısını ortaya koyarak uzun vadede borç ödeme kapasiteleri hakkında bilgi vermektedir.

Finansal kaldıraç oranı: Şirket varlıklarının nasıl finanse edildiğini göstermektedir. Bu oranın yüksek olması finansal riskin de yüksek olması demektir. 
Faaliyet Oranları: Şirket faaliyetlerinin ne kadar verimli kullanıldığını göstermektedir. İşletmelerin varlık veya varlık gruplarının ve bu varlık gruplarının sağladığı gelirlere oranla ne ölçüde yatırım yaptığını ve bu varlıkların ne ölçüde verimli kullandığını değerlemede kullanılan oranlardır.

Aktif devir hızı: Bu oranla varlıkların her bir lirası ile elde edilen gelirler hesaplanmaktadır. Bu oranın yüksek olması şirketlerin hemen hemen tam kapasiteyle çalıştığını göstermektedir. Bu oran şirketlerin karlılığını belirleyen önemli faktörlerden biridir.

Alacak devir hızı: Şirketlerin alacaklarının tahsil etme yeteneğini ve likiditesini gösteren bu oranın yüksek olması alacakların kısa sürede tahsil edildiğini göstermektedir.

Duran varlıklar devir hızı: Bu oran şirketlerin maddi duran varlıklara gereğinden fazla yatırım yapıp yapmadığını ve şirketlerde âtıl kapasitenin olup olmadığını göstermektedir.

Karlıllk oranlarl: Şirketlerin geçmişteki kazanç gücü ve faaliyetlerinin etkinliği hakkında bilgi vermektedir.

Özsermaye karlılığı: Bu oran şirket varlıklarının ne derecede verimli kullanıldığını göstermektedir. Bu oran başarı ve karlılık durumu analizlerinde önemli bir orandır ve yüksek olması arzu edilmektedir.

Aktif karlıllğg: Şirket yatırımlarının karlılı̆ıııı gösteren bu oran şirket aktiflerinin ne ölçüde karlı kullanıldığının tespit edilmesinde kullanılmaktadır.

Faaliyet kâr marjı: Satışlar üzerinden faaliyet karlılığını gösteren bu oran şirketlerin ana faaliyetlerinden ne derecede kar sağladığının belirlenmesi için de kullanılmaktadır.

Brüt kâr marjı: Satılan malların satış fiyatı ile maliyetleri arasında ne derecede bir marjın olduğunu, kaynakların düşük fiyatlarla temin edilip edilmediğini göstermektedir.

Net kâr marjl: Şirket satışlarının vergi sonrası karlılığını gösteren bu oran şirketlerin uyguladığı çeşitli politika ve kararların oluşturduğu sonuçlar hakkında bilgi vermektedir.

\subsection{Bulgular}

Çalışmada ilk olarak Avrupa'nın önde gelen 5 havayolu şirketinin bilançolarından yararlanarak finansal oranlar hesaplanmış ve bu oranlarla şirketlerin 2009-2018 yılları arasındaki finansal performansı WASPAS ve EDAS yöntemleri ile değerlendirilmiştir. Yöntemlerin uygulamasında kriterlerin ağırlık değeri Entropi yöntemiyle belirlenmiştir. Her yılın analizinde ilgili yılın kriter ağılıkları kullanılmıştır. Kriter ağırlıkları Tablo 3'de verilmiştir. Yıllar itibariyle incelendiğinde en etkili kriterlerin yıllara göre değiştiği görülmektedir. "Aktif devir hızı", "duran varlıklar devir hızı" ve "finansal kaldıraç oranı" kriterlerinin en az etkili kriterler olduğunu söylemek mümkündür. Kriter ağırlıkları yöntemin doğası gereği her yıl için ayrı ayrı belirlenmiştir. Daha sonra kriter ağırlıkları dikkate alınarak ve eşit kabul edilerek her iki yönteme göre iki farklı yaklaşımla finansal performans ölçümü yapılmışırı. WASPAS ve EDAS yöntemleriyle şirketlerin performansları her yıl için ayrı ayrı ölçülmüştür. Kriter ağırlıkları eşit kabul edilerek WASPAS yöntemi ile değerlendirilen havayolları şirketlerinin finansal performansları ve başarı sıralaması Tablo 4'de verilmiştir. Kriter ağırlıkları dikkate alınarak yapılan analiz sonuçları ise Tablo 5'de verilmiştir. Şirketlerin çizgi grafiği biçimindeki performans göstergeleri ise Şekil 2 ve 3'de verilmiştir. Tablolar ve grafikler karşılaştıııldığında performans ölçümlerinde kriter ağırlıklarının anlamlı olmadığı görülmektedir.

Tablo 3. Kriter Ağırlıkları

\begin{tabular}{lcccccccccccc}
\hline Yıl & $\begin{array}{c}\text { Cari } \\
\text { oran }\end{array}$ & $\begin{array}{c}\text { Asit } \\
\text { test } \\
\text { oranı }\end{array}$ & $\begin{array}{c}\text { Nakit } \\
\text { oranı }\end{array}$ & $\begin{array}{c}\text { Aktif } \\
\text { devir } \\
\text { hızı }\end{array}$ & $\begin{array}{c}\text { Alacak } \\
\text { devir } \\
\text { hızı }\end{array}$ & $\begin{array}{c}\text { Duran } \\
\text { varlıklar } \\
\text { devir } \\
\text { hızı }\end{array}$ & $\begin{array}{c}\text { Finansal } \\
\text { kaldıraç } \\
\text { oranı }\end{array}$ & $\begin{array}{c}\text { Özsermaye } \\
\text { karlılığı }\end{array}$ & $\begin{array}{c}\text { Aktif } \\
\text { karlılığı }\end{array}$ & $\begin{array}{c}\text { Faaliyet } \\
\text { kâr } \\
\text { marjı }\end{array}$ & $\begin{array}{c}\text { Brüt } \\
\text { kâr } \\
\text { marjı }\end{array}$ & $\begin{array}{c}\text { Net } \\
\text { kâr } \\
\text { marjı }\end{array}$ \\
\hline $\mathbf{2 0 0 9}$ & 0,0436 & 0,0458 & 0,1387 & 0,0187 & 0,1169 & 0,0152 & 0,0043 & 0,0716 & 0,0956 & 0,2105 & 0,1401 & 0,0990 \\
$\mathbf{2 0 1 0}$ & 0,0594 & 0,0641 & 0,2044 & 0,0333 & 0,1542 & 0,0242 & 0,0046 & 0,1071 & 0,0326 & 0,0572 & 0,1537 & 0,1052 \\
$\mathbf{2 0 1 1}$ & 0,0513 & 0,0564 & 0,1555 & 0,0217 & 0,0701 & 0,0157 & 0,0024 & 0,1515 & 0,1468 & 0,1725 & 0,0437 & 0,1124 \\
$\mathbf{2 0 1 2}$ & 0,0908 & 0,0978 & 0,2730 & 0,0287 & 0,1274 & 0,0192 & 0,0083 & 0,0455 & 0,0215 & 0,0980 & 0,0933 & 0,0965 \\
$\mathbf{2 0 1 3}$ & 0,0669 & 0,0722 & 0,1048 & 0,0199 & 0,0970 & 0,0191 & 0,0087 & 0,1994 & 0,0927 & 0,1602 & 0,0791 & 0,0802 \\
$\mathbf{2 0 1 4}$ & 0,0520 & 0,0677 & 0,1192 & 0,0682 & 0,0618 & 0,0178 & 0,0105 & 0,1048 & 0,2119 & 0,0615 & 0,1162 & 0,1083 \\
$\mathbf{2 0 1 5}$ & 0,1044 & 0,1118 & 0,0901 & 0,0421 & 0,0932 & 0,0386 & 0,0130 & 0,0366 & 0,1567 & 0,0878 & 0,0480 & 0,1777 \\
$\mathbf{2 0 1 6}$ & 0,0443 & 0,0480 & 0,0579 & 0,0281 & 0,0816 & 0,0319 & 0,0089 & 0,1495 & 0,1516 & 0,1498 & 0,0262 & 0,2224 \\
$\mathbf{2 0 1 7}$ & 0,0468 & 0,0490 & 0,0532 & 0,0132 & 0,1349 & 0,0135 & 0,0071 & 0,1216 & 0,1817 & 0,1432 & 0,0198 & 0,2160 \\
$\mathbf{2 0 1 8}$ & 0,0493 & 0,0532 & 0,0682 & 0,0167 & 0,1677 & 0,0176 & 0,0076 & 0,0884 & 0,1770 & 0,0845 & 0,0423 & 0,2276 \\
\hline
\end{tabular}


Tablo 4. Havayolu Şirketlerinin WASPAS'a Göre 10 Yıllık Performans Sıralaması (Kriter Ağırlıkları Eşit)

\begin{tabular}{|c|c|c|c|c|c|c|c|c|c|c|}
\hline & 2009 & 2010 & 2011 & 2012 & 2013 & 2014 & 2015 & 2016 & 2017 & 2018 \\
\hline Air France (KLM) & 0,385 & 0,529 & 0,461 & 0,486 & 0,453 & 0,336 & 0,352 & 0,481 & 0,221 & 0,408 \\
\hline Easyjet & 0,531 & 0,612 & 0,785 & 0,618 & 0,700 & 0,617 & 0,689 & 0,602 & 0,581 & 0,583 \\
\hline Lufthansa & 0,317 & 0,454 & 0,339 & 0,415 & 0,305 & 0,160 & 0,378 & 0,349 & 0,490 & 0,281 \\
\hline Ryanair & 0,622 & 0,751 & 0,825 & 0,812 & 0,713 & 0,710 & 0,717 & 0,801 & 0,841 & 0,834 \\
\hline THY & 0,833 & 0,550 & 0,353 & 0,583 & 0,403 & 0,513 & 0,518 & 0,225 & 0,400 & 0,500 \\
\hline
\end{tabular}

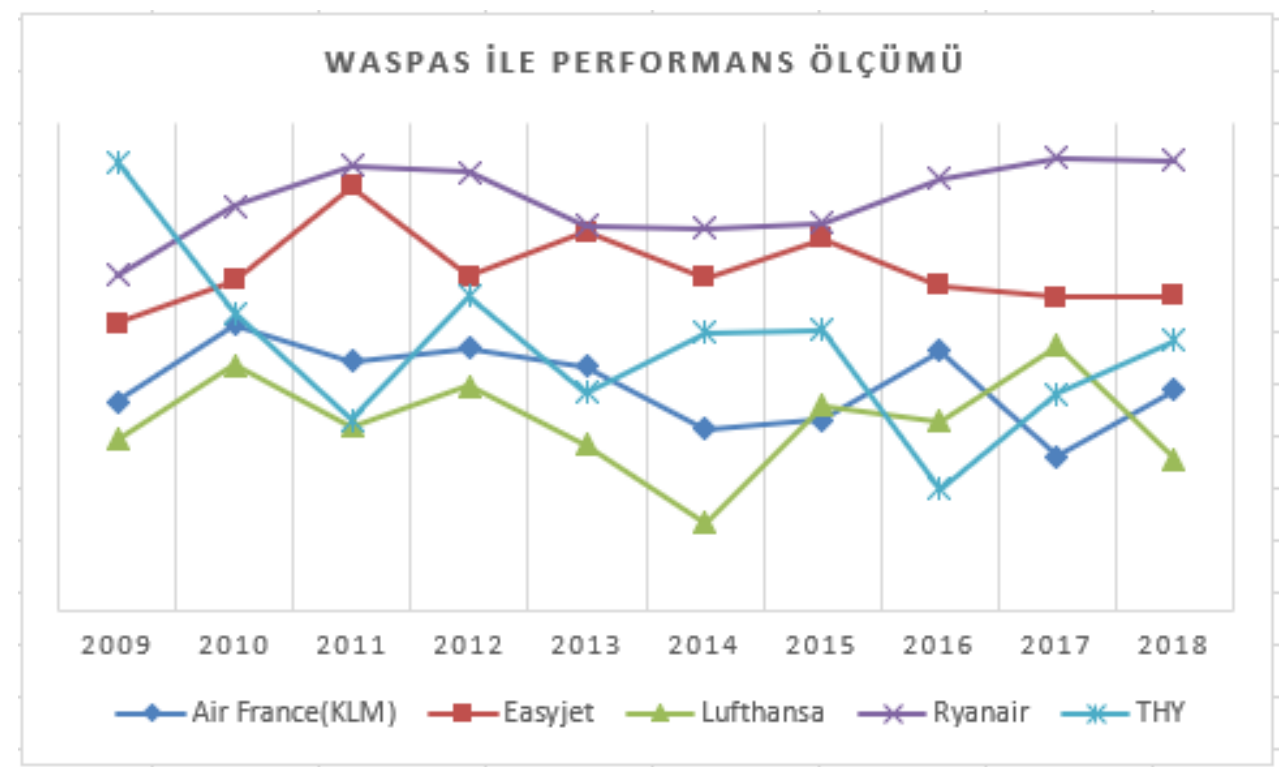

Şekil 2. Havayolu Şirketlerinin WASPAS'a Göre 10 Yıllık Performans Grafiği

\section{(Kriter Ağırlıkları Eşit)}

Kriter ağırlıklarının eşit kabul edildiği WASPAS yöntemi analizine göre tüm yıllar itibariyle performansı en yüksek şirketin Ryanair olduğu görülmektedir. Bu şirketi Easyjet takip etmektedir. 2015 yılına kadar son sırayı Lufthansa şirketi almıştır. Bu şirketin 2016 yılından itibaren performansını artırdı̆̆ 1 ve 3. sıraya yerleştiği anlaşılmaktadır. THY ve Air France şirketleri 2015 yılına kadar 3 . ve 4. sırayı dönüşümlü olarak almışlardır. 2016'dan sonra bu şirketler yine dönüşümlü olarak son sıralara yerleşmiştir.

Tablo 5. Havayolu Şirketlerinin WASPAS'a Göre 10 Yıllık Performans Sıralaması (Kriter Ağırlıkları Farklı)

\begin{tabular}{lcccccccccc} 
& $\mathbf{2 0 0 9}$ & $\mathbf{2 0 1 0}$ & $\mathbf{2 0 1 1}$ & $\mathbf{2 0 1 2}$ & $\mathbf{2 0 1 3}$ & $\mathbf{2 0 1 4}$ & $\mathbf{2 0 1 5}$ & $\mathbf{2 0 1 6}$ & $\mathbf{2 0 1 7}$ & $\mathbf{2 0 1 8}$ \\
\cline { 2 - 10 } Air France (KLM) & 0,208 & 0,389 & 0,379 & 0,427 & 0,373 & 0,233 & 0,208 & 0,344 & 0,100 & 0,226 \\
Easyjet & 0,430 & 0,583 & 0,742 & 0,522 & 0,591 & 0,642 & 0,651 & 0,453 & 0,395 & 0,403 \\
Lufthansa & 0,211 & 0,320 & 0,207 & 0,340 & 0,223 & 0,093 & 0,328 & 0,335 & 0,568 & 0,179 \\
Ryanair & 0,550 & 0,779 & 0,922 & 0,872 & 0,682 & 0,675 & 0,813 & 0,890 & 0,961 & 0,946 \\
THY & 0,792 & 0,437 & 0,190 & 0,534 & 0,313 & 0,492 & 0,498 & 0,093 & 0,217 & 0,366 \\
\hline
\end{tabular}




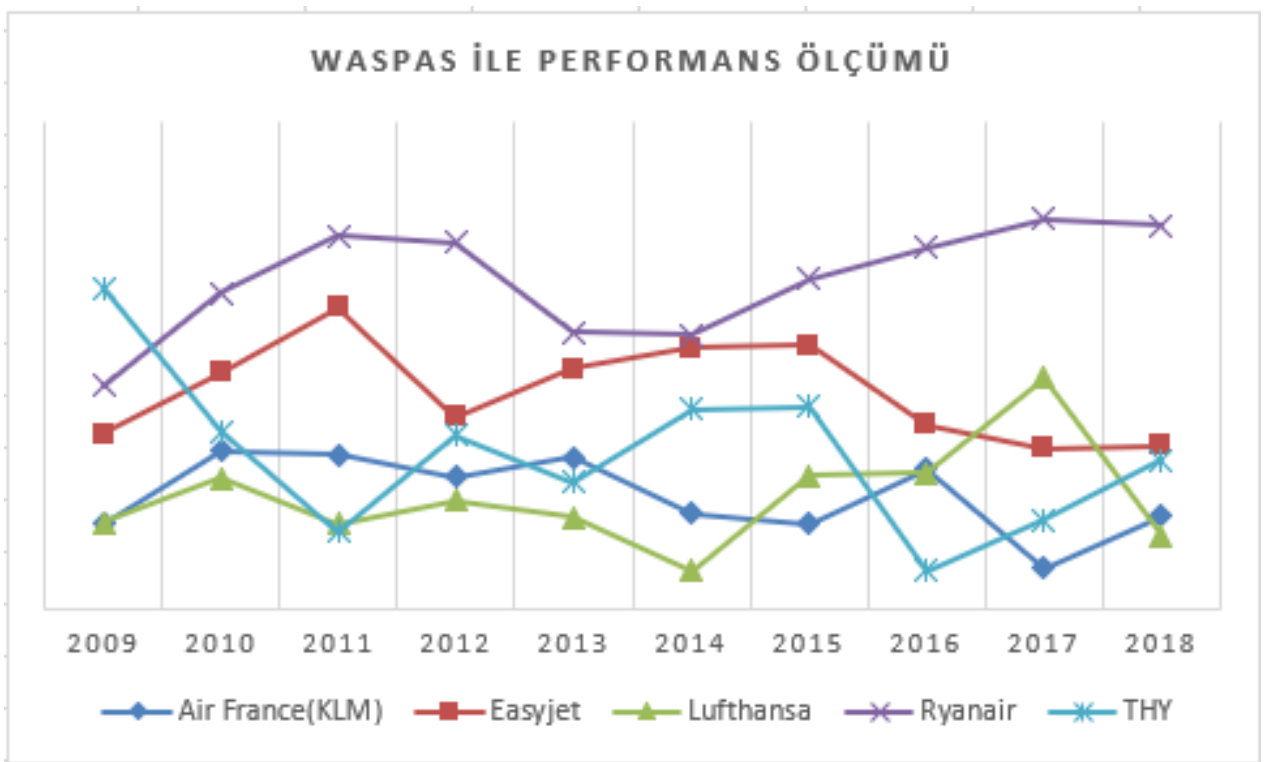

Şekil 3. Havayolu Şirketlerinin WASPAS’a Göre 10 Yıllık Performans Grafiği

(Kriter Ağırlıkları Farklı)

Kriter ağırlıklarının farklı ele alındı̆̆ WASPAS analizinde de durum değişmemiş̧tir. Ryanair 1. sırayı alırken Easyjet 2. sırayı almıştır. 2014 yılına kadar son sırayı Lufthansa şirketi almıştır. THY ve Air France şirketlerinin 3. ve 4. sırayı dönüşümlü olarak aldıkları görülmektedir. 2015 yılından itibaren bu durum değişmiş ve bu şirketler dönüşümlü olarak 4. ve 5. siraya gerilemişlerdir. Şekil 2 ve Şekil 3'de verilen grafikler birlikte değerlendirildiğinde anlamlı bir farkın olmadığı görülmektedir. THY her iki grafiğe göre de 2011 ve 2016 yıllarında en kötü performansını göstermiştir. Dikkat çekici bir başka durum ise 2014 yılından itibaren performans artışı gösteren Lufthansa'nın 2018 yılında dip yapmasidır.

EDAS yöntemi ile değerlendirilen havayollarının finansal performansları ve başarı sıralaması ise Tablo 6 ve 7 'de ve verilmiştir.

Tablo 6. Havayolu Şirketlerinin EDAS’a Göre 10 Yıllık Performans Sıralaması (Kriter Ağırlıkları Eşit)

\begin{tabular}{lllllllllll} 
Air France (KLM) & 0,221 & 0,222 & 0,201 & 0,129 & 0,445 & 0,423 & 0,154 & 0,361 & 0,061 & 0,208 \\
Easyjet & 0,403 & 0,413 & 0,767 & 0,443 & 0,758 & 0,788 & 0,703 & 0,561 & 0,451 & 0,496 \\
Lufthansa & 0,020 & 0,041 & 0,019 & 0,011 & 0,001 & 0,010 & 0,107 & 0,166 & 0,385 & 0,012 \\
Ryanair & 0,640 & 0,783 & 0,896 & 0,864 & 0,867 & 0,932 & 0,843 & 0,950 & 0,930 & 0,939 \\
THY & 0,967 & 0,226 & 0,144 & 0,385 & 0,190 & 0,550 & 0,385 & 0,001 & 0,168 & 0,389 \\
\hline
\end{tabular}

WASPAS yöntemi ile yapıldığı gibi EDAS yöntemi ile de şirketler iki farklı şekilde analiz edilmiştir. İlkinde kriter ağırlıkları eşit kabul edilmiş ikincisinde ise Entropi yöntemi ile hesaplanan kriter ağırlıkları sürece katılmıştır. Her iki yaklaşımın sonuçlarına göre şirketlerin performansları anlamlı bir farklılık göstermemiştir. Her iki yaklaşımda da Ryanair 1., Easyjet 2. sırayı almıştır. Lufthansa 2014 yılına kadar her iki yaklaşımda son sırayı alırken bu tarihten itibaren performans artışı gösterdiği gözlenmiştir. THY ve Air France ise 3. ve 4. sıraları yıllara göre dönüşümlü olarak almışlardır. Her iki yaklaşımda da Easyjet firmasının 2014 yılından itibaren performans düşüşü sergilediği görülmektedir.

EDAS ve WASPAS yöntemleri birlikte değerlendirildiğinde her iki yönteme göre farklı yaklaşımlar dikkate alındığında şu sonuçlara varılmıştır:

1. Ryanair şirketinin her dört yaklaşıma göre en yüksek performansı elde ettiği belirlenmiştir.

2. Easyjet şirketinin her dört yaklaşıma göre de 2017 yılı dışındaki tüm yıllar itibariyle 2. sırayı aldığı belirlenmiştir. Ayrıca bu şirketin 2014 yılından itibaren performans kayıpları yaşadığı görülmektedir.

3. Lufthansa şirketi 2014 yılına kadar son sırayı alırken bu tarihten sonra performansını artırdığı ancak 2017 yılından itibaren düşüşe geçtiği gözlemlenmiştir.

4. THY ve Air France şirketleri 2015 yılına kadar 3. ve 4. sıraları değişmeli olarak alırken bu yıldan sonra 4. ve 5. sıraları dönüşümlü olarak almışlardır. 


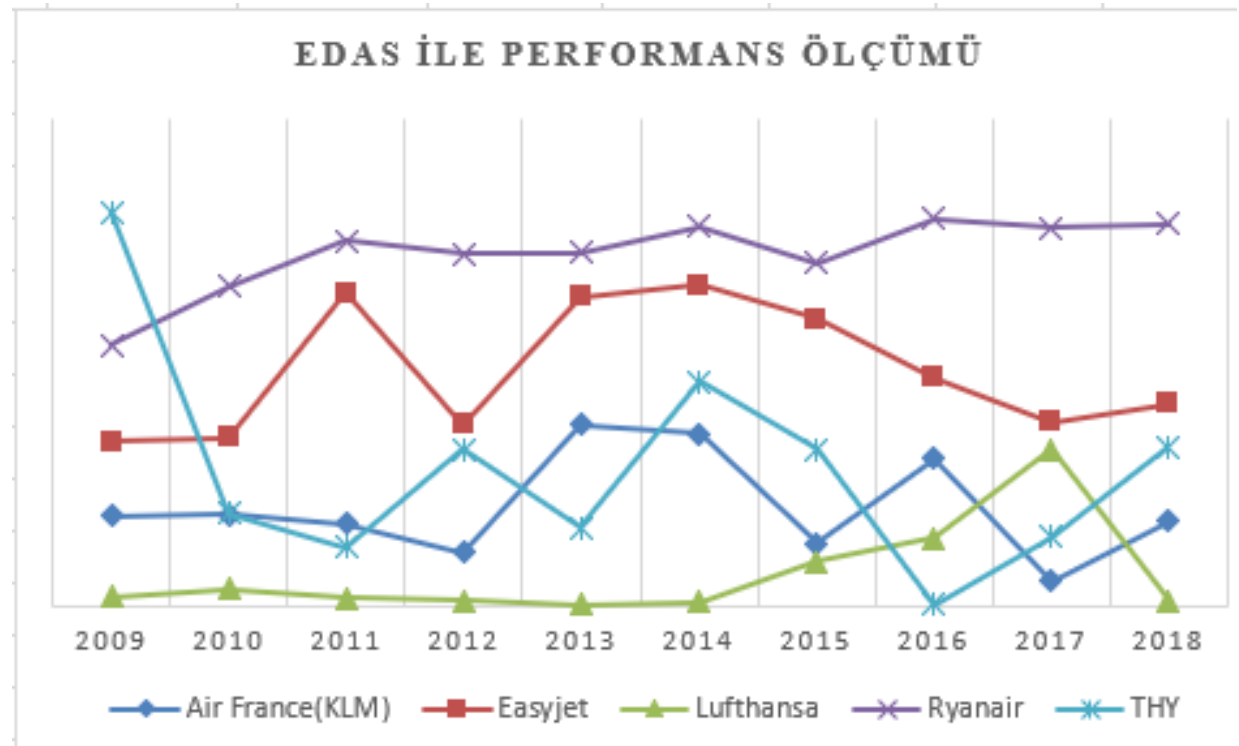

Şekil 4. Havayolu Şirketlerinin EDAS'a Göre 10 Yıllık Performans Grafiği (Kriter Ağırlıkları Eşit)

Tablo 7. Havayolu Şirketlerinin EDAS'a Göre 10 Yıllık Performans Sıralaması (Kriter Ağırlıkları Farklı)

\begin{tabular}{lcccccccccc} 
& $\mathbf{2 0 0 9}$ & $\mathbf{2 0 1 0}$ & $\mathbf{2 0 1 1}$ & $\mathbf{2 0 1 2}$ & $\mathbf{2 0 1 3}$ & $\mathbf{2 0 1 4}$ & $\mathbf{2 0 1 5}$ & $\mathbf{2 0 1 6}$ & $\mathbf{2 0 1 7}$ & $\mathbf{2 0 1 8}$ \\
\cline { 2 - 10 } Air France(KLM) & 0,087 & 0,143 & 0,143 & 0,094 & 0,562 & 0,430 & 0,054 & 0,321 & 0,008 & 0,062 \\
Easyjet & 0,379 & 0,511 & 0,744 & 0,405 & 0,685 & 0,959 & 0,663 & 0,474 & 0,364 & 0,373 \\
Lufthansa & 0,013 & 0,028 & 0,004 & 0,009 & 0,001 & 0,007 & 0,173 & 0,345 & 0,610 & 0,007 \\
Ryanair & 0,624 & 0,901 & 0,982 & 0,969 & 0,895 & 0,957 & 0,944 & 0,989 & 0,993 & 0,988 \\
THY & 0,961 & 0,197 & 0,039 & 0,298 & 0,165 & 0,618 & 0,438 & 0,000 & 0,135 & 0,331 \\
\hline
\end{tabular}

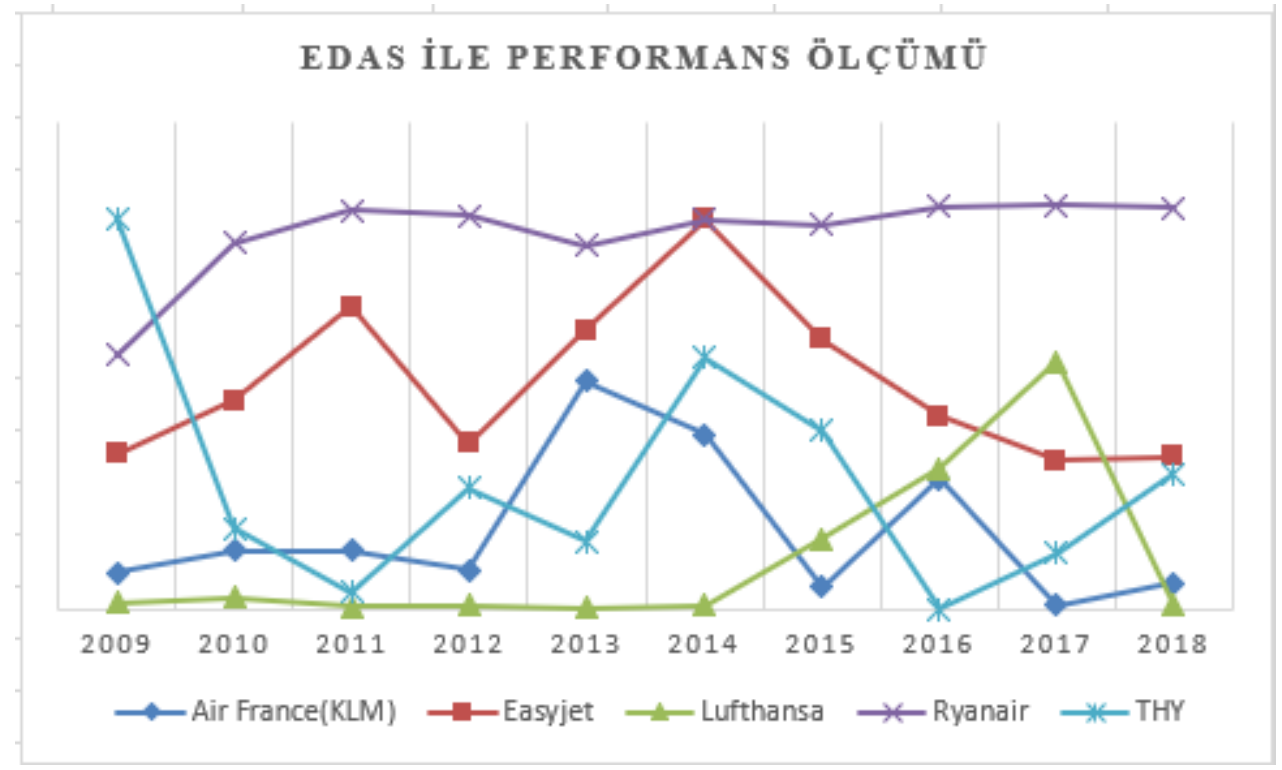

Şekil 5. Havayolu Şirketlerinin EDAS’a Göre 10 Yıllık Performans Grafiği

(Kriter Ağırlıkları Farklı)

\section{Sonuç ve Değerlendirme}

Hızlı bir şekilde gelişen ve büyüyen havayolu taşımacılığı sektörü dünya ekonomisi ve ülkelerin ekonomik ve sosyo-kültürel gelişmelerine fayda sağlayan en önemli sektörlerden biridir. Uluslararası ortamda havayolu şirketlerinin yoğun rekabeti nedeniyle 
varlıklarını başarılı bir şekilde sürdürebilmeleri için finansal performans anlamında yüksek ve başarılı bir performansa sahip olmaları gereklidir.

Çalışmada Avrupa'nın önde gelen 5 havayolu şirketinin 2009-2018 yıllarındaki on yıllık finansal performansı ÇKKV yöntemlerinden WASPAS ve EDAS yöntemleri ile on farklı kriter dikkate alınarak analiz edilmiş ve finansal performans bakımından başarı sıralaması ortaya konmuştur. Çalışmada her bir yöntem iki farklı yaklaşımla uygulanmıştır. Birincisi kriter ağırlıkları dikkate alınmadan ikincisi ise kriter ağırlıkları dikkate alınarak. Kriter ağırlıkları Entropi yöntemiyle her yıl için belirlenmiştir. Yani kriterlerin ağırlıkları yıllara göre değişiklik göstermektedir. En etkili kriterlerin yıllara göre değiştiği görülmektedir. "Aktif devir hızı", "duran varlıklar devir hızı" ve "finansal kaldıraç oranı" kriterlerinin en az etkili kriterler olduğunu söylemek mümkündür. Çalışmada kullanılan kriterlerden "finansal kaldıraç oranı" maliyet yönlü iken diğer kriterler fayda yönlüdür.

Analiz neticesinde finansal performansı en yüksek havayolu firmasının her iki yöntem ve dört farklı yaklaşıma göre Ryanair olduğu belirlenmiştir. Ryanair şirketini Easyjet takip etmiştir. Easyjet şirketi her iki yöntemin kriter ağılıkları dikkate alınmadan yapılan analize göre 2. sırayı alırken; kriter ağırlıkları dikkate alınarak yapılan analizde 2017 yılından itibaren 3. sıraya düştüğü görülmüştür. Lufthansa'nın 2015 yılına kadar her iki yöntemin her iki yaklaşımına göre son sırada yer aldı̆̆ı görülmüştür. Bu yıldan itibaren bu şirketin performansında 1 veya 2 basamak yükselmesine rağmen 2018 yılında tekrar son sıraya yerleşmiştir. THY ve Air France şirketlerin 3. ve 4. sırayı yıllara göre dönüşümlü olarak paylaştıkları anlaşılmaktadır. Her iki yönteme göre havayolu şirketlerinin on yıllık finansal performans sıralaması dikkate alındığında; sıralamanın Ryanair, Easyjet, THY, Air France ve Lufthansa şeklinde olduğu görülmektedir.

Finansal performans analizinde en yüksek performansa sahip olan Ryanair ve Easyjet havayolu şirketleri "düşük maliyetli” havayolu şirketleridir. "Düşük tarifeli hizmetler" sunan Ryanair ve Easyjet havayolları zamanla hem yüksek ve istikrarlı gelirlere hem de yolcu sayısı bakımından yüksek doluluk oranlarına ulaşmışlardır. Uygulanan bu strateji ve yükselen doluluk oranları sayesinde satış gelirlerinin ve kar marjlarının arttığı ve bu sayede devir hızlarının ve karlılık oranlarının yükseldiği de düşünülmektedir. Böylelikle bu firmalar havayolu sektörünün ileri gelen yüksek performanslı firmalarından olmayı başarmaktadırlar.

$\mathrm{Bu}$ çalışma ile analiz kapsamında yer alan işletme yöneticilerine kendi ve rakip işletmelerinin durumu hakkında 1şı tutulmaktadır. Çıkan sıralamaya göre performansı düşük işletmelerin rekabet edebilir duruma gelmesi için bir dizi çalışma yaparak gerekli tedbirleri zamanında almaları gerektiği ortaya çıkmıştır.

$\mathrm{Bu}$ konularda ileride çalışma yapmak isteyen araştırmacılar, farklı kriterler kullanarak veya farklı ÇKKV yöntemlerini sürece dahil ederek aynı şirketleri değerlendirebilirler. Ayrıca bu çalışmada Entropi yöntemi ile nesnel olarak hesaplanan kriter ağırlıkları başka nesnel ya da öznel yöntemler kullanılarak belirlenebilir ve analizlerde bu ağırlıklar kullanılabilir. Farklı kriterler kullanıldığında şirketlerin performansını en çok etkileyen kriterleri belirleyerek duyarlılık analizi yapıp sonuçlar yorumlanabilir.

\section{Kaynakça}

Akgün, M., \& Soy Temür, A. (2016). BIST Ulaştırma Endeksine Kayıtlı Şirketlerin Finansal Performanslarının TOPSİS Yöntemi İle Değerlendirilmesi, Uluslararası Yönetim İktisat ve İşletme Dergisi, 30, 173-186.

Akkaya, G. C. (2004). Finansal Rasyolar Yardımıyla Havayolları İşletmelerinin Performansının Değerlendirilmesi. Dokuz Eylül Üniversitesi İktisadi ve İdari Bilimler Fakültesi Dergisi, 19(1), 15-29.

Al Masum, A., \& Tuz-Johora, F. (2012). Performance Evaluation of Selected Ceramic Companies of Bangladesh, Asian Business Review, 1(1), 37-47.

Aldemir, H. Ö., \& Kuyucak, Şengür, F. (2018). Türkiye'de Havayolu Rekabeti Üzerine Yazılmış Lisansüstü Tezlerin İncelenmesi, Journal of Aviation, 2(2), 141-155.

Asker, V. (2017). Veri Zarflama Analizi ile Finansal ve Operasyonel Etkinlik Ölçümü: Geleneksel Havayolu İşletmelerinde Bir Uygulama, Anadolu Üniversitesi Sosyal Bilimler Dergisi, 18(1).153-172.

Avcı, T., \& Çınaroğlu, E. (2018). AHP Temelli TOPSIS Yaklaşımı ile Havayolu İşletmelerinin Finansal Performans Değerlemesi, Cumhuriyet Üniversitesi İktisadi ve İdari Bilimler Dergisi, 19(1), 316-335.

Barros, C. P., \& Wanke, P. (2015). An analysis of African air lines efficiency with two-stage TOPSIS and neural networks, Journal of Air Transport Management, 44, 90-102.

Battal, Ü., (2018). Türkiye'de Havayolu Taşımacılığının Finansman Sorunları: DEMATEL Yöntemi Uygulaması, Ömer Halisdemir Üniversitesi İktisadi ve İdari Bilimler Fakültesi Dergisi, 11(2), 96-111.

Çetin, A., \& Altan, Ş. (2019). Bulanık TOPSİS Yöntemiyle Havayolu Şirketleri Performans Değerlendirmesi: Esenboğa Hava limanında Bir Uygulama, Giresun Üniversitesi İktisadi ve İdari Bilimler Dergisi, 5(1), 40-61. 
Dalak, S., Günay, F., Beyazgül, M., \& Karadeniz, E. (2018). Türkiye'de Faaliyet Gösteren Havayolu Şirketlerinde Finansal Analiz Tekniklerinin Kullanımı Üzerine Bir Araştırma, İşletme ve İktisat Çalışmaları Dergisi, 6(2), 1-14.

Feng, C. M., \&Wang, R. T. (2000). Performance Evaluation for Airlines Including the Consideration Of Financial Ratios, Journal of Air Transport Management, 6(6), 133-142.

Gerede, E. (2015). Havayolu Taşımacılığı ve Ekonomik Düzenlemeler Teori ve Türkiye Uygulaması. Art Ofset Matbaacılık, Ankara.

Gümüş, U. T., \& Bolel, N. (2017). Rasyo Analizleri ile Finansal Performansın Ölçülmesi: Borsa İstanbul'da Faaliyet Gösteren Havayolu Şirketleri'nde Bir Uygulama, Adnan Menderes Üniversitesi Sosyal Bilimler Enstitüsü Dergisi, 4(2). 87-96.

Karami, A., \& Johansson, R. (2014). Utilization Of Multi Attribute Decision Making Techniques To Integrate Automatic and Manual Ranking of Options, Journal Of Information Science and Engineering, 30: 519-534.

Kaya, A., \& Kendirli, S. (201o). Havayolu Şirketlerinde Finansal Bir Araç Olarak Hedging Yönteminin Kullanılması, MANAS Sosyal Araştırmalar Dergisi, 7(4), 113-126.

Kiracı, K., \& Asker, V. (2019). Etkinlik ve Etkinliği Belirleyen Faktörler: Havayolu Şirketleri Üzerine Ampirik Bir İnceleme, Eskişehir Osmangazi Üniversitesi İIBF Dergisi, 14(1), 25-50.

Kiracı, K., \& Bakır, M. (2019). CRITIC Temelli EDAS Yöntemi ile Havayolu İşletmelerinde Performans Ölçümü Uygulaması, Pamukkale Üniversitesi Sosyal Bilimler Enstitüsü Dergisi, 35, 157-174.

Ömürbek, V., \& Kınay, B. (2013), Havayolu Taşımacıllğı Sektöründe TOPSIS Yöntemiyle Finansal Performans Değerlendirmesi, Süleyman Demirel Üniversitesi İktisadi ve İdari Bilimler Fakültesi Dergisi, 18(3), 343-363.

Özbek, A., \& Engür, M. (2018). EDAS Yöntemi ile Lojistik Firma Web Sitelerinin Değerlendirilmesi, Selçuk Üniversitesi, Sosyal Bilimler Meslek Yüksekokulu Dergisi, Sayı 2, S. 417-429.

Özbek, A. (2019). Çok Kriterli Karar Verme Yöntemleri ve Excel ile Problem Çözümü, Seçkin Yayınevi, 2. Baskı, Ankara.

Perçin, S., \& Aldalou, E. (2018). Financial Performance Evaluation of Turkish Airline Companies Using Integrated Fuzzy AHP Fuzzy TOPSIS Model, International Journal of Economic and Administrative Studies, 18. EYI Special Issue, 583-598.

Safaei Ghadikolaei, A., Khalili Esbouei, S., \& Antuchevicien, J. (2014). Applying Fuzzy MCDM For Financial Performance Evaluation of İranian Companies, Technological and Economic Development of Economy, 20(2), 274-291.

Sakız, B. (2017). Finansal Oranlar Kullanılarak Risk Yönetimi ve Havayolu Sektörü-Bir Uygulama, International Conference On Eurasian Economies, 282-290.

Teker, D., Teker, S., \& Güner, A. (2016). Financial Performance of Top 20 Airlines, Procedia -Social and Behavioral Sciences, 235, 603-610.

Wang, T.C., \& Lee, H.D. (2009). Developing A Fuzzy Topsis Approach Based On Subjective Weights And Objective Weights, Expert Systems With Applications, 36 (5): 8980-8985

Wang, Y. J., \& Kao, C. S. (2009). A Fuzzy Multi-Criteria Group Decision-Making Model For The Financial Performance Evaluation of Airlines, Sixth International Conference on Fuzzy Systems and Knowledge Discovery, 3, 193-197.

Wang, Y.-J. (2008). Applying FMCDM To Evaluate Financial Performance of Domestic Airlines in Taiwan, Expert Systems with Applications, 34(3), 1837-1845.

Wanke, P., Barros, C. P., \& Chen, Z. (2015). An Analysis of Asian Airlines Efficiency with Two Stage TOPSIS and MCMC Generalized Linear Mixed Models, International Journal of Production Economics, 169, 110-126

Wu, J., Sun, J., Liang, L., \& Zha Y. (2011). Determination of Weights for Ultimate Cross Efficiency Using Shannon Entropy, Expert Systems with Applications, 38 (5): 5162-5165.

Zhang, H., Gu, C., Gu, L., \& Zhang, Y. (2011). The Evaluation of Tourism Destination Competitiveness by TOPSIS \& Information Entropy - A Case in The Yangtze River Delta of China, Tourism Management, 32: 443-451 
Ek:

Tablo 8: Havayolu Şirketlerinin 2009 Yılı Mali Verileri

\begin{tabular}{|l|c|c|c|c|c|c|c|c|c|c|c|c|}
\hline & $\begin{array}{c}\text { Cari } \\
\text { oran }\end{array}$ & $\begin{array}{c}\text { Asit } \\
\text { test } \\
\text { oranı }\end{array}$ & $\begin{array}{c}\text { Nakit } \\
\text { oranı }\end{array}$ & $\begin{array}{c}\text { Aktif } \\
\text { devir } \\
\text { hızı }\end{array}$ & $\begin{array}{c}\text { Alacak } \\
\text { devir } \\
\text { hızı }\end{array}$ & $\begin{array}{c}\text { Duran } \\
\text { varlıklar } \\
\text { devir } \\
\text { hızı }\end{array}$ & $\begin{array}{c}\text { Finansal } \\
\text { kaldıraç } \\
\text { oranı }\end{array}$ & $\begin{array}{c}\text { Ozzermaye } \\
\text { karlılı̆ı }\end{array}$ & $\begin{array}{c}\text { Aktif } \\
\text { karlılığı }\end{array}$ & $\begin{array}{c}\text { Faaliyet } \\
\text { kar } \\
\text { marjı }\end{array}$ & $\begin{array}{c}\text { Brüt } \\
\text { kar } \\
\text { marjı }\end{array}$ & $\begin{array}{c}\text { Net } \\
\text { kar } \\
\text { marjı }\end{array}$ \\
\hline Air France & 0,710 & 0,660 & 0,330 & 0,830 & 11,760 & 1,160 & 0,800 & 0,140 & 0,030 & 0,000 & 0,070 & 0,030 \\
\hline Easyjet & 1,400 & 1,400 & 0,740 & 0,590 & 8,890 & 0,980 & 0,640 & 0,050 & 0,020 & 0,030 & 0,190 & 0,030 \\
\hline Lufthansa & 0,570 & 0,570 & 0,030 & 74,000 & 27,970 & 0,790 & 0,820 & 0,040 & 0,010 & 0,020 & 0,070 & 0,010 \\
\hline Ryanair & 1,840 & 1,840 & 1,150 & 0,370 & 56,080 & 0,610 & 0,620 & 0,070 & 0,030 & 0,040 & 0,020 & 0,070 \\
\hline THY & 1,440 & 1,360 & 0,560 & 0,820 & 15,850 & 1,220 & 0,600 & 0,160 & 0,070 & 0,100 & 0,260 & 0,080 \\
\hline
\end{tabular}

Tablo 9: Havayolu Şirketlerinin 2010 Yılı Mali Verileri

\begin{tabular}{|l|c|c|c|c|c|c|c|c|c|c|c|c|}
\hline & $\begin{array}{c}\text { Cari } \\
\text { oran }\end{array}$ & $\begin{array}{c}\text { Asit } \\
\text { test } \\
\text { oranı }\end{array}$ & $\begin{array}{c}\text { Nakit } \\
\text { oranı }\end{array}$ & $\begin{array}{c}\text { Aktif } \\
\text { devir } \\
\text { hızı }\end{array}$ & $\begin{array}{c}\text { Alacak } \\
\text { devir } \\
\text { hızı }\end{array}$ & $\begin{array}{c}\text { Duran } \\
\text { varlıklar } \\
\text { devir } \\
\text { hızı }\end{array}$ & $\begin{array}{c}\text { Finansal } \\
\text { kaldıraç } \\
\text { oranı }\end{array}$ & $\begin{array}{c}\text { Ozzsermaye } \\
\text { karlılığ }\end{array}$ & $\begin{array}{c}\text { Aktif } \\
\text { karlılığ } \mathbf{I}\end{array}$ & $\begin{array}{c}\text { Faaliyet } \\
\text { kar } \\
\text { marjı }\end{array}$ & $\begin{array}{c}\text { Brüt } \\
\text { kar } \\
\text { marjı }\end{array}$ & $\begin{array}{c}\text { Net } \\
\text { kar } \\
\text { marjı }\end{array}$ \\
\cline { 2 - 12 } & 0,770 & 0,710 & 0,360 & 0,760 & 9,800 & 1,060 & 0,800 & 0,290 & 0,060 & 0,080 & 0,020 & 0,070 \\
\hline Easyjet & 1,420 & 1,420 & 0,860 & 0,600 & 12,380 & 0,970 & 0,630 & 0,080 & 0,030 & 0,070 & 0,280 & 0,050 \\
\hline Lufthansa & 0,640 & 0,630 & 0,040 & 0,740 & 26,940 & 1,030 & 0,790 & 0,120 & 0,030 & 0,100 & 0,110 & 0,040 \\
\hline Ryanair & 1,980 & 1,970 & 0,950 & 0,310 & 52,480 & 0,520 & 0,620 & 0,110 & 0,040 & 0,170 & 0,130 & 0,130 \\
\hline THY & 1,370 & 1,310 & 0,320 & 0,790 & 14,570 & 1,180 & 0,650 & 0,080 & 0,030 & 0,060 & 0,210 & 0,030 \\
\hline
\end{tabular}

Tablo 10: Havayolu Şirketlerinin 2011 Yılı Mali Verileri

\begin{tabular}{|c|c|c|c|c|c|c|c|c|c|c|c|c|}
\hline & $\begin{array}{l}\text { Cari } \\
\text { oran }\end{array}$ & $\begin{array}{c}\text { Asit } \\
\text { test } \\
\text { oranı }\end{array}$ & $\begin{array}{l}\text { Nakit } \\
\text { oranı }\end{array}$ & $\begin{array}{c}\text { Aktif } \\
\text { devir } \\
\text { hızı }\end{array}$ & $\begin{array}{c}\text { Alacak } \\
\text { devir } \\
\text { hızı }\end{array}$ & $\begin{array}{c}\text { Duran } \\
\text { varlıklar } \\
\text { devir } \\
\text { hızı }\end{array}$ & $\begin{array}{c}\text { Finansal } \\
\text { kaldıraç } \\
\text { oranı }\end{array}$ & $\begin{array}{c}\text { Özsermaye } \\
\text { karlılığ }\end{array}$ & $\underset{\text { karlılığı }}{\text { Aktif }}$ & $\begin{array}{c}\text { Faaliyet } \\
\text { kar } \\
\text { marjı }\end{array}$ & $\begin{array}{c}\text { Brüt } \\
\text { kar } \\
\text { marjı }\end{array}$ & $\begin{array}{c}\text { Net } \\
\text { kar } \\
\text { marj1 }\end{array}$ \\
\hline Air France & 0,700 & 0,640 & 0,250 & 0,890 & 13,730 & 1,170 & 0,780 & 0,130 & 0,030 & 0,020 & 0,060 & 0,030 \\
\hline Easyjet & 1,480 & 1,480 & 0,930 & 0,760 & 20,540 & 1,240 & 0,620 & 0,130 & 0,050 & 0,080 & 0,220 & 0,070 \\
\hline Lufthansa & 0,480 & 0,470 & 0,030 & 0,840 & 26,940 & 1,070 & 0,810 & 0,030 & 0,010 & 0,050 & 0,090 & 0,010 \\
\hline Ryanair & 1,890 & 1,890 & 1,100 & 0,330 & 55,890 & 0,550 & 0,660 & 0,130 & 0,040 & 0,170 & 0,130 & 0,130 \\
\hline THY & 1,020 & 0,960 & 0,390 & 0,720 & 15,440 & 0,960 & 0,730 & 0,001 & 0,001 & 0,010 & 0,170 & 0,070 \\
\hline
\end{tabular}

Tablo 11: Havayolu Şirketlerinin 2012 Yılı Mali Verileri

\begin{tabular}{|l|c|c|c|c|c|c|c|c|c|c|c|c|}
\hline & $\begin{array}{c}\text { Cari } \\
\text { oran }\end{array}$ & $\begin{array}{c}\text { Asit } \\
\text { test } \\
\text { oranı }\end{array}$ & $\begin{array}{c}\text { Nakit } \\
\text { oranı }\end{array}$ & $\begin{array}{c}\text { Aktif } \\
\text { devir } \\
\text { hızı }\end{array}$ & $\begin{array}{c}\text { Alacak } \\
\text { devir } \\
\text { hızı }\end{array}$ & $\begin{array}{c}\text { Duran } \\
\text { varlıklar } \\
\text { devir } \\
\text { hızı }\end{array}$ & $\begin{array}{c}\text { Finansal } \\
\text { kaldırac } \\
\text { oranı }\end{array}$ & $\begin{array}{c}\text { Ozsermaye } \\
\text { karlılığı }\end{array}$ & $\begin{array}{c}\text { Aktif } \\
\text { karlıı̆ı }\end{array}$ & $\begin{array}{c}\text { Faaliyet } \\
\text { kar } \\
\text { marjı }\end{array}$ & $\begin{array}{c}\text { Brüt } \\
\text { kar } \\
\text { marjı }\end{array}$ & $\begin{array}{c}\text { Net } \\
\text { kar } \\
\text { marjı }\end{array}$ \\
\cline { 2 - 13 } Easyjet & 0,770 & 0,720 & 0,350 & 0,950 & 13,680 & 1,330 & 0,860 & 0,340 & 0,050 & 0,030 & 0,060 & 0,050 \\
\hline Lufthansa & 1,050 & 1,050 & 0,510 & 0,880 & 15,740 & 1,280 & 0,580 & 0,140 & 0,060 & 0,090 & 0,220 & 0,070 \\
\hline Ryanair & 2,140 & 0,540 & 0,080 & 0,770 & 31,800 & 1,050 & 0,810 & 0,150 & 0,030 & 0,100 & 0,070 & 0,040 \\
\hline THY & 0,860 & 0,800 & 1,490 & 0,390 & 60,040 & 0,680 & 0,630 & 0,170 & 0,060 & 0,190 & 0,140 & 0,160 \\
\hline
\end{tabular}


Tablo 12: Havayolu Sirketlerinin 2013 Y1lı Mali Verileri

\begin{tabular}{|c|c|c|c|c|c|c|c|c|c|c|c|c|}
\hline & $\begin{array}{l}\text { Cari } \\
\text { oran }\end{array}$ & $\begin{array}{c}\text { Asit } \\
\text { test } \\
\text { oranı }\end{array}$ & $\begin{array}{l}\text { Nakit } \\
\text { oranı }\end{array}$ & $\begin{array}{c}\text { Aktif } \\
\text { devir } \\
\text { hızl }\end{array}$ & $\begin{array}{c}\text { Alacak } \\
\text { devir } \\
\text { hızı }\end{array}$ & $\begin{array}{c}\text { Duran } \\
\text { varlıklar } \\
\text { devir } \\
\text { hızı }\end{array}$ & $\begin{array}{c}\text { Finansal } \\
\text { kaldıraç } \\
\text { oranı }\end{array}$ & $\begin{array}{c}\text { Özsermaye } \\
\text { karlılığı }\end{array}$ & $\begin{array}{c}\text { Aktif } \\
\text { karlılığı }\end{array}$ & $\begin{array}{c}\text { Faaliyet } \\
\text { kar } \\
\text { marjı }\end{array}$ & $\begin{array}{l}\text { Brüt } \\
\text { kar } \\
\text { marjı }\end{array}$ & $\begin{array}{c}\text { Net } \\
\text { kar } \\
\text { marjı }\end{array}$ \\
\hline Air France & 0,730 & 0,680 & 0,340 & 1,000 & 14,380 & 1,460 & 0,910 & 0,790 & 0,070 & 0,001 & 0,080 & 0,070 \\
\hline Easyjet & 1,050 & 1,050 & 0,730 & 0,950 & 21,620 & 1,410 & 0,540 & 0,200 & 0,090 & 0,120 & 0,250 & 0,090 \\
\hline \begin{tabular}{|l} 
Lufthansa \\
\end{tabular} & 0,490 & 0,490 & 0,100 & 0,700 & 30,360 & 0,910 & 0,790 & 0,090 & 0,010 & 0,060 & 0,050 & 0,030 \\
\hline Ryanair & 1,970 & 1,970 & 0,650 & 0,430 & 68,090 & 0,740 & 0,630 & 0,170 & 0,060 & 0,190 & 0,100 & 0,150 \\
\hline THY & 0,680 & 0,630 & 0,200 & 0,740 & 16,360 & 0,900 & 0,730 & 0,100 & 0,030 & 0,080 & 0,180 & 0,040 \\
\hline
\end{tabular}

Tablo 13: Havayolu Şirketlerinin 2014 Y1lı Mali Verileri

\begin{tabular}{|c|c|c|c|c|c|c|c|c|c|c|c|c|}
\hline & $\begin{array}{l}\text { Cari } \\
\text { oran }\end{array}$ & $\begin{array}{c}\text { Asit } \\
\text { test } \\
\text { oranı }\end{array}$ & $\begin{array}{l}\text { Nakit } \\
\text { oranı }\end{array}$ & $\begin{array}{c}\text { Aktif } \\
\text { devir } \\
\text { hızı }\end{array}$ & $\begin{array}{c}\text { Alacak } \\
\text { devir } \\
\text { hızı }\end{array}$ & $\begin{array}{c}\text { Duran } \\
\text { varlıklar } \\
\text { devir } \\
\text { hızı }\end{array}$ & $\begin{array}{c}\text { Finansal } \\
\text { kaldıraç } \\
\text { oranı }\end{array}$ & $\begin{array}{c}\text { Özsermaye } \\
\text { karlılığı }\end{array}$ & $\begin{array}{c}\text { Aktif } \\
\text { karlılığı }\end{array}$ & $\begin{array}{c}\text { Faaliyet } \\
\text { kar } \\
\text { marjı }\end{array}$ & $\begin{array}{c}\text { Brüt } \\
\text { kar } \\
\text { marjı }\end{array}$ & $\begin{array}{c}\text { Net } \\
\text { kar } \\
\text { marjı }\end{array}$ \\
\hline Air France & 0,610 & 0,560 & 0,270 & 1,070 & 14,420 & 1,550 & 1,030 & 0,330 & 0,001 & 0,030 & 0,080 & 0,001 \\
\hline Easyjet & 0,890 & 0,890 & 0,300 & 0,100 & 22,310 & 1,390 & 0,520 & 0,210 & 0,100 & 0,130 & 0,260 & 0,100 \\
\hline Lufthansa & 0,260 & 0,250 & 0,040 & 0,700 & 24,080 & 0,830 & 0,830 & $-0,210$ & $-0,040$ & 0,060 & 0,020 & 0,050 \\
\hline Ryanair & 1,510 & 1,720 & 0,760 & 0,430 & 65,230 & 0,710 & 0,630 & 0,160 & 0,060 & 0,170 & 0,050 & 0,140 \\
\hline THY & 0,770 & 0,720 & 0,170 & 0,760 & 22,850 & 0,950 & 0,710 & 0,190 & 0,050 & 0,070 & 0,180 & 0,080 \\
\hline
\end{tabular}

Tablo 14: Havayolu Şirketlerinin 2015 Yılı Mali Verileri

\begin{tabular}{|c|c|c|c|c|c|c|c|c|c|c|c|c|}
\hline & $\begin{array}{l}\text { Cari } \\
\text { oran }\end{array}$ & $\begin{array}{c}\text { Asit } \\
\text { test } \\
\text { oranı }\end{array}$ & $\begin{array}{l}\text { Nakit } \\
\text { oranı }\end{array}$ & $\begin{array}{c}\text { Aktif } \\
\text { devir } \\
\text { hızı }\end{array}$ & $\begin{array}{c}\text { Alacak } \\
\text { devir } \\
\text { hızı }\end{array}$ & $\begin{array}{c}\text { Duran } \\
\text { varlıklar } \\
\text { devir } \\
\text { hızı } \\
\end{array}$ & $\begin{array}{c}\text { Finansal } \\
\text { kaldıraç } \\
\text { oranı }\end{array}$ & $\begin{array}{c}\text { Özsermaye } \\
\text { karlılığı }\end{array}$ & $\begin{array}{c}\text { Aktif } \\
\text { karlılığı }\end{array}$ & $\begin{array}{c}\text { Faaliyet } \\
\text { kar } \\
\text { marjı }\end{array}$ & $\begin{array}{c}\text { Brüt } \\
\text { kar } \\
\text { marjı }\end{array}$ & $\begin{array}{c}\text { Net } \\
\text { kar } \\
\text { marjı }\end{array}$ \\
\hline Air France & 0,630 & 0,580 & 0,260 & 1,100 & 14,270 & 1,630 & 0,990 & 0,470 & 0,001 & 0,040 & 0,100 & 0,001 \\
\hline Easyjet & 0,720 & 0,720 & 0,370 & 0,960 & 22,410 & 1,300 & 0,530 & 0,240 & 0,110 & 0,150 & 0,290 & 0,120 \\
\hline Lufthansa & 0,240 & 0,230 & 0,040 & 0,690 & 35,950 & 0,830 & 0,800 & 0,230 & 0,050 & 0,100 & 0,140 & 0,070 \\
\hline Ryanair & 1,720 & 1,720 & 0,350 & 0,350 & 70,880 & 0,660 & 0,670 & 0,210 & 0,070 & 0,240 & 0,120 & 0,200 \\
\hline THY & 0,810 & 0,760 & 0,230 & 0,600 & 27,360 & 0,750 & 0,700 & 0,210 & 0,060 & 0,100 & 0,200 & 0,100 \\
\hline
\end{tabular}

Tablo 16: Havayolu Şirketlerinin 2016 Y1lı Mali Verileri

\begin{tabular}{|c|c|c|c|c|c|c|c|c|c|c|c|c|}
\hline & $\begin{array}{l}\text { Cari } \\
\text { oran }\end{array}$ & $\begin{array}{c}\text { Asit } \\
\text { test } \\
\text { oranı }\end{array}$ & $\begin{array}{l}\text { Nakit } \\
\text { oranı }\end{array}$ & $\begin{array}{c}\text { Aktif } \\
\text { devir } \\
\text { hızı }\end{array}$ & $\begin{array}{c}\text { Alacak } \\
\text { devir } \\
\text { hızı }\end{array}$ & $\begin{array}{c}\text { Duran } \\
\text { varlıklar } \\
\text { devir } \\
\text { hızı }\end{array}$ & $\begin{array}{c}\text { Finansal } \\
\text { kaldıraç } \\
\text { oranı }\end{array}$ & $\begin{array}{c}\text { Özsermaye } \\
\text { karlılığı }\end{array}$ & $\begin{array}{c}\text { Aktif } \\
\text { karlılığı }\end{array}$ & $\begin{array}{c}\text { Faaliyet } \\
\text { kar } \\
\text { marjı }\end{array}$ & $\begin{array}{c}\text { Brüt } \\
\text { kar } \\
\text { marjı }\end{array}$ & $\begin{array}{c}\text { Net } \\
\text { kar } \\
\text { marjı }\end{array}$ \\
\hline Air France & 0,750 & 0,690 & 0,390 & 1,080 & 13,300 & 1,620 & 0,940 & 0,610 & 0,030 & 0,040 & 0,130 & 0,030 \\
\hline Easyjet & 0,920 & 0,920 & 0,460 & 0,840 & 22,380 & 1,130 & 0,510 & 0,160 & 0,080 & 0,110 & 0,260 & 0,100 \\
\hline Lufthansa & 0,280 & 0,270 & 0,050 & 0,560 & 31,390 & 0,700 & 0,780 & 0,210 & 0,050 & 0,160 & 0,100 & 0,080 \\
\hline Ryanair & 1,430 & 1,430 & 0,370 & 0,440 & 75,140 & 0,780 & 0,680 & 0,430 & 0,140 & 0,290 & 0,170 & 0,310 \\
\hline THY & 0,800 & 0,750 & 0,320 & 0,450 & 22,090 & 0,560 & 0,720 & 0,001 & 0,001 & 0,010 & 0,120 & 0,001 \\
\hline
\end{tabular}


Tablo 17: Havayolu Şirketlerinin 2017 Y1lı Mali Verileri

\begin{tabular}{|c|c|c|c|c|c|c|c|c|c|c|c|c|}
\hline & $\begin{array}{l}\text { Cari } \\
\text { oran }\end{array}$ & $\begin{array}{c}\text { Asit } \\
\text { test } \\
\text { oranı }\end{array}$ & $\begin{array}{l}\text { Nakit } \\
\text { oranı }\end{array}$ & $\begin{array}{c}\text { Aktif } \\
\text { devir } \\
\text { hızı }\end{array}$ & $\begin{array}{c}\text { Alacak } \\
\text { devir } \\
\text { hızı }\end{array}$ & $\begin{array}{c}\text { Duran } \\
\text { varlıklar } \\
\text { devir } \\
\text { hızı }\end{array}$ & $\begin{array}{c}\text { Finansal } \\
\text { kaldıraç } \\
\text { oranı }\end{array}$ & $\begin{array}{l}\text { Özsermaye } \\
\text { karlılı̆g }\end{array}$ & $\underset{\text { karlılığ }}{\text { Aktif }}$ & $\begin{array}{c}\text { Faaliyet } \\
\text { kar } \\
\text { marjı }\end{array}$ & $\begin{array}{c}\text { Brüt } \\
\text { kar } \\
\text { marjı }\end{array}$ & $\begin{array}{c}\text { Net } \\
\text { kar } \\
\text { marjı }\end{array}$ \\
\hline Air France & 0,750 & 0,710 & 0,390 & 0,860 & 11,950 & 1,240 & 0,920 & 0,070 & 0,001 & 0,001 & 0,160 & 0,000 \\
\hline Easyjet & 1,040 & 1,040 & 0,430 & 0,680 & 14,770 & 0,960 & 0,530 & 0,110 & 0,050 & 0,100 & 0,300 & 0,080 \\
\hline Lufthansa & 0,310 & 0,310 & 0,060 & 0,530 & 36,070 & 0,690 & 0,730 & 0,320 & 0,090 & 0,210 & 0,130 & 0,160 \\
\hline Ryanair & 1,560 & 1,560 & 0,410 & 0,410 & 89,650 & 0,670 & 0,630 & 0,300 & 0,110 & 0,320 & 0,160 & 0,270 \\
\hline THY & 0,850 & 0,800 & 0,440 & 0,580 & 17,810 & 0,720 & 0,710 & 0,030 & 0,010 & 0,110 & 0,200 & 0,020 \\
\hline
\end{tabular}

Tablo 18: Havayolu Şirketlerinin 2018 Yılı Mali Verileri

\begin{tabular}{|c|c|c|c|c|c|c|c|c|c|c|c|c|}
\hline & $\begin{array}{l}\text { Cari } \\
\text { oran }\end{array}$ & $\begin{array}{c}\text { Asit } \\
\text { test } \\
\text { oranı }\end{array}$ & $\begin{array}{l}\text { Nakit } \\
\text { oranı }\end{array}$ & $\begin{array}{c}\text { Aktif } \\
\text { devir } \\
\text { hızı }\end{array}$ & $\begin{array}{c}\text { Alacak } \\
\text { devir } \\
\text { hizı }\end{array}$ & $\begin{array}{c}\text { Duran } \\
\text { varlıklar } \\
\text { devir hızı }\end{array}$ & $\begin{array}{c}\text { Finansal } \\
\text { kaldıraç } \\
\text { oranı }\end{array}$ & $\begin{array}{c}\text { Özsermaye } \\
\text { karlılı̆gı }\end{array}$ & $\underset{\text { karlılı̆̆ }}{\text { Aktif }}$ & $\begin{array}{c}\text { Faaliyet } \\
\text { kar } \\
\text { marjı }\end{array}$ & $\begin{array}{c}\text { Brüt } \\
\text { kar } \\
\text { marjı }\end{array}$ & $\begin{array}{c}\text { Net } \\
\text { kar } \\
\text { marjı }\end{array}$ \\
\hline $\begin{array}{l}\text { Air } \\
\text { France }\end{array}$ & 0,630 & 0,580 & 0,290 & 0,910 & 12,100 & 1,250 & 0,940 & 0,220 & 0,010 & 0,050 & 0,130 & 0,020 \\
\hline Easyjet & 0,970 & 0,970 & 0,500 & 0,670 & 11,550 & 0,940 & 0,540 & 0,110 & 0,050 & 0,100 & 0,330 & 0,080 \\
\hline Lufthansa & 0,250 & 0,240 & 0,060 & 0,530 & 24,420 & 0,650 & 0,710 & 0,040 & 0,010 & 0,190 & 0,100 & 0,020 \\
\hline Ryanair & 1,230 & 1,230 & 0,440 & 0,420 & 89,130 & 0,630 & 0,640 & 0,320 & 0,120 & 0,320 & 0,170 & 0,280 \\
\hline THY & 0,870 & 0,830 & 0,320 & 0,580 & 20,940 & 0,740 & 0,710 & 0,130 & 0,040 & 0,120 & 0,220 & 0,060 \\
\hline
\end{tabular}

